DEPARTMENTS OF WUCLEAR AND MECHANICAL ENGINEERING MASSACHUSETTS INSTITUTE OF TECHNOLOGY

Cambridge, Massachusetts 02139

$\mathrm{July}, 1977$

\title{
PRESSURE DROP MEASUREMENTS IN LMPBR \\ WIRE WRAPPED BLANKET ASSEMBLIES
}

by

c. Cniu

J. Hawley

W.M. Rohsenow

N.E. Todreas

ERDA Research and Development

Contract E(11-1)-2245

U.S. Energy Research and Development Administration

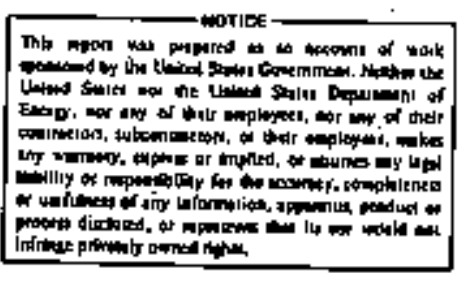

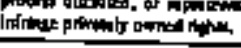




\section{DISCLAIMER}

This report was prepared as an account of work sponsored by an agency of the United States Government. Neither the United States Government nor any agency Thereot, nor any of their employees, makes any warranty, express or implied, or assumes any legal liability or responsibility for the accuracy, completeness, or usefulness of any information, apparatus, product, or process disclosed, or represents that its use would not infringe privately owned rights. Reference herein to any specific commercial product, process, or service by trade name, trademark, manufacturer, or otherwise does not necessarily constitute or imply its endorsement, recommendation, or favoring by the United States Government or any agency thereof. The views and opinions of authors expressed herein do not necessarlly state or reflect those of the United States Government or any agency thereof. 


\section{DISCLAIMER}

Portions of this document may be illegible in electronic image products. Images are produced from the best available original document. 
Reports and Papers Published under iIT Coolant Mixing in LMF

A. 2uaryarly Progress Reports (Available from National Technical Information Service, U.S. Department of Commerce, Springrield, VA 22151)

Coc-2245-1 Period June 1, 1972 - November 30, 1972

co0-2245-2 Period December 1, 1972 - February 28, 1973

Co0-2245-3 Period March I, 1973 - May 31, 1973

Co0-2245-6 Period June 1, 1973 - August 31, 1973

c00-2245-7 Period September 1, 1973 - November 30, 1973

c00-2245-8 Period December 1, 1973 - February 28, 1974

C00-2245-10 Per1od March 1, 1974 - May 31, 1974

Coo-2245-13 Period June 1, 1974 - August 31, 1974

Co0-2245-14 Period September 1, 1974 - November 31, 1974

C00-2245-15 Period December 1, 1974 - February 28, 1975

Co0-2245-23 Period March 1, 1975 - May 31, 1975

Coo-2245-25 Period June 1, :975 - Rugust 31, 1975

Co0-2245-26 Period September 1, 1975 - November 30, 1975

co0-2245-28 Per1od Decenber 1, 1975 - February 29, 1976

CoO-2245-30 Period March 1, 1976 - May 31, 1976

coc-2245-31 Period June 1, 2976 - August 31, 1.976

coo-2245-34 Period September 1, 1976 - November 30, 1976

c00-2245-38 Period December 1, 1976 - February 28, 1977

C00-2245-50 Period March I, 1977 \& May 31, 1977

CoO-2245-53 Period June 1, 1977 - August 31, 1977 
Reports Issued Under This Contregt

B. Topical Reports (Avaslable from Hational Technical Information Service, U.S. Departiont or Commerce, Springfield, VA 22151)

E. Khan and N. Todreas, "A Review of Recent Analytical and Experimental Studies Applicable to LiraR Fuel and Blanket Assembly Design," COO-2245-4TR, HIT, Seoz. 1973.

E. Khan, W. Rohsenow, A. Sonin and $\mathrm{N}$. Tocreas, "A Simplified Approach for Predicting Temperature Distribution in Wire Wrapped Assemblies, "Coo-2245-5TR, MET, sept. 1973.

T. Eaton and W. Todreas, "Instrumentation Methods for Interchannel Coolant Mixing Studies in Hire-Hap Spaced iuclear Fuel Assemblies," Co0-2245-9TR, MIT, June 1974.

Y.B. Chen, K. Ip, N.E. Todreas, "Velocit: Measurements in Edge Subchannels of Wire Wrapoed EMFBR Fuel Azsemblies," COO-2245IITR, MIT, September 1974.

E. Khan, N. Todreas, W. Rohsenow, A.A. SchIn, "Analysis of Mixing Data Relevant to Wire-Hrapoed Fuei Assembly ThermalHydraulic Design," CO0-2245-12TR, MIN, SEptember 1974 .

E. Khan, W. Rohsenow, A. Sonin, N. Todreas, "A Porous Body Model for Predicting Temperature Dissmibions in Wire Wrapped Fuel and Blanket Assemblies of a LllFBR," COO-2245I6TR, MIT, March 1975 .

E. Khan, W.M. Rohsenow, A. Sonin, N. Todreas, "Input Parameters to the ENERGY Code (To be used with the EVIERGY Code Manual) COO-2245-17TR, MIT, May 1975.

E. Khan, W. Rohsenow, A.' Son1n, N. Todreas, "Manual for FiNERGY codes I, II, III,", CO0-2245-18TR, MIT, iNay 1975

E. Khan, W. Rohsenow, A. Sonin, N. Todrecs, "Manual Eor ENERGY Codes I, II, III Computer Programs, "COO-2245-18TR Revision 1, MIT, July 1976 .

$P$. Carajilescov and N. Todreas, "Experimental and Analytical Study of Axial Turbulent Flows in an Interlor Subchannel of a Bare Rod Bundle," COO-2245-19TR, MiT.

B. Chen and N. Todreas, "Prediction of Coolant Pemperature Field in a Breeder Reactdr Including Intsrassembly Heat Transfer," COO-2245-20TR, MIT, May 197j.

$B$. Chen and $N$. Todreas, "Prediction of $C=21$ ant Tenperature Field in a Breeder Reactor Inlcuding Inienassembly U̦eat Transfer," COO-2245-20TR Revision 1, l.IT, Decernber 1976.

F. Carre and $N$. Todreas, "Development of Input Data to EMERGY Code for Analysis of Reactor Fuel Bundies," CoO-2245-2l'rR, MIT, May 1975 . 
Reports Issited Under This Contract

3. Topteal Reports, Continued

H. Ninokata and N.E. Todreas, "Turbulent Ifomentum Exchange Coefficients for Reactor Fuel Bundle Analysis," Co0-224522TR, MIT, June 1975.

$R$. Anoba and $N$. Todreas, "Coolant tixing in LMFBR Rod Bundles and Dutlet Plenum Mixjng Transients," COO-2245-24TR, Aldust 1975.

B. Bosy, "Fabrication Details for Wire Wrapped Fuel Asseribly Components," Coo-2245-27TR, MIT, November 1975.

Ralph G. Bennett and Michael $\mathrm{k}$. Golay, "Interferometric Investigation of Turbulentiy Fluctuating Temperature in an LMPER outlet Plenum Geometry," COO-2245-29TR, MIT, June 1976.

N.E. Todreas, "Analysis Methods for LMFBR Wire Wrapped Bundles," COO-2245-32TR, MIT, November 1976.

R.L. Basehore and N.E. Todreas, "Development of Stability Criteria and an Interassembly Conduction bodel for the

Thermal-Hydrallics Code SUPERENERGY," CO0-2245-33TR, IIIT December 1976.

Robert Masterson and Ne1l E. Todreas, "Analysis of the Feasibility of Implementing an Implicit Temporal Differencing Scheme in the SUPERENERGY Code," COO-2245-35TR, MIT, February 1977 .

S. Glazer, C. Chilu and is. Todreas, "Collection and Evaluation of Salt Mixing Data with the Real Time Data Acquisition Systern," CO0-2245-36TR, MIT, April 1977.

B. Mikic, E.U. Khan and N.E. Todreas "An Approximate ifethod for Fredicting Temperature Distribution in Wire Wrapped Fuel Assemblies of a LMFBR," COO-2245-37TR, MIT, April 1977.

C. Chiu and N. Todreas, "Development of a Technique for Subchannel Flow Rate Measurements in LMFBR Nire Wrapped Assemblies," COO-2245-39TR, July 1977

C. Chlu and N. Todreas, "thra Blanket Assembly Pre-Test Predictions by SUPERENERIV," COO-2245-40TR, July 1977

C. Chiu and i. Todreas, "Flon Spliz for a IMPBR 4" yine Wrapped Slanket Assembli " C00-2245-41TR, July 1977

C. Chiu and $N$. Todreas, "stat1o Pressure and Pressure Droo for a LAFBR 4" Wire Wrasped Blankes Assembly, "COO-2245$42 \mathrm{TR}, \mathrm{JUI} Y 1977$ 
B. Topical Reports, Continued

c. Chiu and $\mathrm{W}$. Todreas, "Mixing Experiments for a LMRBR 4" Hro trapped Blanket Assemb1y, "CO0-2245-43TR, July 1977

Y1 B1t Chen and Michael W. Golay, "Coolant Mixing in the LMFBR cutlet Plenum," COO-2245-44sR, June 1977.

J. KeIIy and N. Todreas, "Turbulent Interchange in Triangular Apray Eere Rod Bundles," COO-2245-45TR, July 1977

K.L. Besehore and N.E. Todreas, "Assessment of the Need to Incorporate a Variabie Sul Flow Hodel into the ENERCY code," COO-2245-46TR, July 1977.

K.L. Basehore and it. Todreas, "Analysis of the ThermalHydrauiic Behavicr in the CRBR Secondary Control Assembly, Incluaing Interassenbiy Heat Transiter Effects," Co0-2245-47TR, July 1977 .

J.G. Bartzis and N.E. Todreas, "Eydrodynamic Behavior of a Bare Rod Buncle," COO-2245-48TR, June 1977.

M.R. Fakori-Monazah and N.E. Todreas, "Measurement and Aralysis of Flo; Hall Shear Stress in an Interior Subchannel of Triangular Array Rods," COO-2245-49TR, Augus: 1977.

A.S. Eanson and N.E. Todreas, "Fluid Mixing Studies in an Hexagonal 6l-Pin, Wire-Wrapped Rod Bundle," C00-2245-51TR, August 1977 .

S. Glezer, N. Todreas, W. Rohsenow, and A. Sonin, "Transenergy $S, M$ - Computer Codes for Coolant Temperature Prediction in LMFBR Cores During Transient Events," c00-2245-52TR, Jaruary 1977 .

C. Chis, W.N. Rohsenow and N.E. Todreas, "Mixing Experiments In an liternating W1re Wrapped Assembly," COO-2245-54TR, MIT, December 1977.

C. Chiu, W.M. Rohsenow and N. E. Todrtas, "Sweeping Flow Mixing Model for Wire Wrapped LMFBR Assemblies," Co0-224555TR, ITIT, Decenber 1977.

C. Chs.2, W.M. Rohsenow and N.E. Todreas, "Lumped Subchannel Flon adel for LMFBR bire Wrapped Assemblies," Co0-2245-56TR MIT, DEsember 1977. 


\section{Reports Issued under this Contract}

\section{Papers and Summaries}

Yi B1n Chen, Ka-Lam Ip, Neil E. Todreas, "Velocity Measurements in Edge Channels of Wire-Wrapped LMFBR Fuel Assemblies," American Nuclear Society Transactions vol. I9, 1974, po. 323-324.

P. Carajilescov, N. Todreas, "Experimental and Analytichl Study of Axlal Turbulent Flows in an Interior Subcriannel of a Bare Rod Bundle," J. of Heat Transfen, Vol. 98 , No. 2, Nay 1976, pp. 262-268 (Included as Ropendix to Quarterly Progress Report, COO-2245-15).

E. Khan, W. Rohsenow, A. Sonin, N. Todreas, "A Porous Body Model for Predicting Temperature Distribution in Wre-frapped Fuel Rod Assemblies," Nuclear Engineering and Design, 35 (1975) 1-12.

E. Khan, W. Rohsenot, A. Sonin, N. Todreas, "A Porous Body Model for Predicting Temperature D1stribution in Wire-Wrapped Rod Assemblies Operating in Combined Forced and Free Convection," Nuclear Engineering and Design, 35 (1975) 199-211.

Raloh G. Benrett and Michael w. Golay, "Development of an optical Method for Measurement of Temperature Fluctuation in Turbulent Flows," American Nuclear Society Transactions, Vol. 22, 1975, $\bar{p} .581$.

B. Chen and N. Todreas, "Prediction of the Coolant Temperature Field in a Breeder Reactor Including Interassembly Heat Transfer, "N Nulear Englneering and Design 35, (1975) 423-440 (Included as Appendix to Quarteriy Progress Report, Co0-2245-23).

R. Bennett and $M . W$. Golay, "Interferometric Investigation of Turbulentiy sicuctuating Temperature in an IMPBR outiet Plenum Geometry," Accepted for the ASME Winter Annual Meeting, Dec., 1976, (Included as Appendix in Quarterly Progress Report, COO-2245-30).

B.B. Mikic, E.U. Khan, N.E. Todreas, "An Approximate Method for Predicting Terperature Distribution in Wire Wrapped Fuel Assemblitas of a irguid Metal Fast Breeder Reactor, "Pech. Res. Comm., Vol. 3, 353-360 (1976). 
C. Papers and Summartes (Continued)

L. Wolr, R. Karimi, I.Y. K1m, C.N. Wong, M.K. Yeung "2-D Thermoelastic Analysis of LiMFBR Fuel Rod Claddings," Paper $c 4 / d$, 4 th International Conf. Structural Mechanics in Reactor Technology, San Francisco, August 1977.

M. Yeung, L. WoIf, "Effective Conduction Mixing Lengths for Subchannel Analysis of Finite Hexagonal LMFBR Bundles," ANS Meeting, New York, June 1977.

C. Chlu and N. Todreas, "Flow Split Measurements In An LMFBR Radial Blanket Assembly," ANS Meeting, New York, June 1977. 
"This report was prepared as an account of Governmentsponsored work. Neither the United States, or the Energy Researci and Development Adminfstration nor any person acting on behalf of the Commission

A. Makes any warranty or representation, expressed or 1mplied, with respect to the accuracy, completeness or usefulness of the information contained in this report, or that the use of any Information, apparatus method, or process disclosed in this report may not infringe privately owned rights; or

B. Assumes any liabilities with respect to the use of, or for damages resulting from the use of, any information, apparatus, method, or process disclosed in this report.

As used in the above, 'person acting on behalf' of the Commission' includes any employee or contractor of the Administration or employee of such contractor, to the extent that such employee or contractor prepares, disseminates, or provides access to, any information pursuant to his employment or contract with the Administration or his employment with such contractor." 


\section{ABSTRACT}

In this experiment, measurements of subchannel static pressure for an interior and edge subchannel were taken at two elevations in two wire-wrapped 6l-pin bundles. One of the bundies has geometric characteristics of $P / D=1.067$ and $H / D=8.0$ ( 4 1nch lead length and 0.501 1nch sod diameter) and the other bundle has geometric characteristics of $P / D=$ 1.067 and $H / D=4.0$ (2 1nch lead length and 0.501 inch rod diameter).

The bundle aterage friction factors as well as the local subchannel friction factors for both 1nterior and edge subchannels were determined from the experimental static pressure data. The average subchannle flow rates for both edge and interior subchannels were determined in a separate experiment. Results show that two correlations suggested by Rehme and Novendstern for the bundle average friction ractor cannot predict the data within the range of exper1mental error. The bundle average friction factors for both bundles under test were underestimated by Fehme's correlation and overestimated by Novendstern's correlation.

The results of the local subchannel friction factors Indicate the effect of the wire wrap lead length is more pronotunced in the interfor subchannel priction factor than in the edge subchannel friction factor. As the wire wrap lead length decreases, both interfor and edge subchannel friction factors increase. 
The authors would like to thank Mr. Mike Corradini for his valuable suggestions and editing. Thanks are also due to Ms. Jacqueline Humbert for her tireless editing and proofreading of the final draft of this report.

The authors wish to thank Malka Grinkorn and Ginny O'Keefe for their typing.

Sponsorship of this work through the Energy Research and Development Administration is also acknowledged. 


\section{NOMENCLATURE}

D

De

Des

$\mathrm{D}_{\mathrm{e} 2}$

DeI

$\mathbf{f}_{b}$

$f_{s}$

$\mathrm{f}_{\mathrm{s}}$

$f_{\text {sl }}$

H

L

$n$

$N_{1}$

$\mathrm{N}_{2}$

N 3

${ }^{N}$

$P$

Re

$\mathrm{Re}_{2} \ldots$ Edge subchannel Reynoids number, defined by Eq. (4-12)

Fuel pin diameter, ( $f t$ )

Average bundle equivalent hydraulic diameter, defined as the ratio of four times the total bundle area to the total bundle wetted perimeter, (ft).

Subchannel equivalent hydraulic diameter.

Equivalent hydraulic dlameter of edge subchannels, (ft)

Equivalent hydraulic diameter of interior subchannels, ( $f^{t} t$ )

Bundle average frlction factor, defined by Eq. (4-1)

Local subchannel friction factor, defined by

Eq. $(4-8)$

Local edge subchannel friction factor

Local interior subchannel friction factor

Wire wrap lead (or pitch), (ft)

Bundle or subchannel length over which the pressure drop is measured, (ft)

Total number of subchannels in test bundles

Total number of interior subchannels in test bundles

Total number of edge subchannels in test bundles

Total number of corner subchannels in test bundles

Total number of rods in test bundles

Fuel rod pitch ( $f t$ )

Average bundle Reynolds number characterlzed by the bundle average equivalent hydraulic diameter and the bundle average velocity 


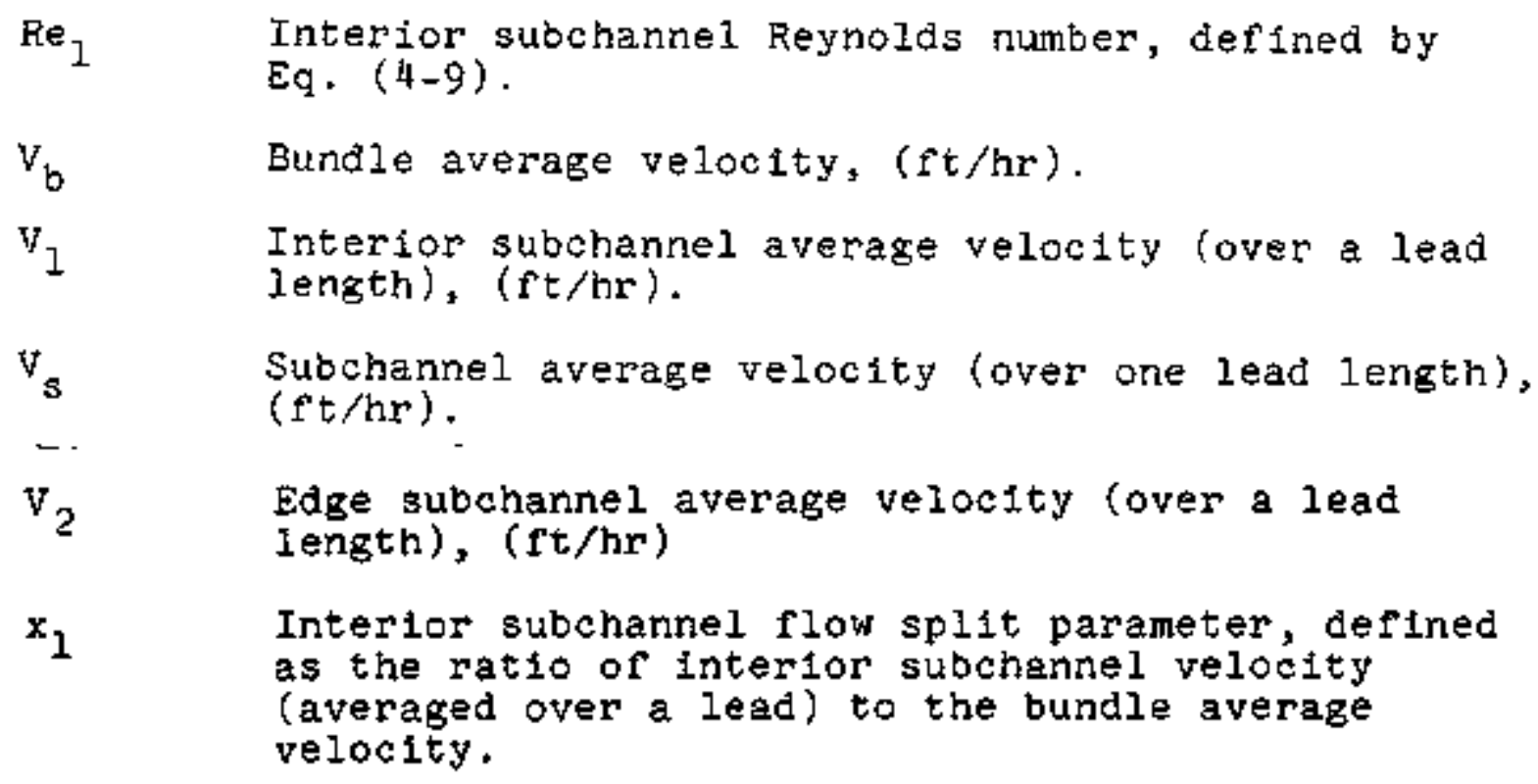

$x_{2}$ Edge subchannel flow split parameter, defined as the rat 10 of the edge subchannel velocity (averaged over a lead) to the bundle average velocity

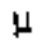

Fluld viscocity $(1 \mathrm{bm} / \mathrm{hr}-\mathrm{rt})$

p Fluid density (Ibm/cu. $\mathrm{ft}$ )

$\Delta P_{b} \quad$ Average bundle pressure drop (lbf/sq. ft)

$\Delta \mathrm{P}_{\mathrm{S}} \quad$ Subchannel pressure drop ( $1 \mathrm{bf} / \mathrm{sq} . \mathrm{ft}$ )

$\Delta P_{s 1}$ Inter1or subchannel pressure drop (lbf/sq. $f t$ )

$\overline{\Delta F_{\mathrm{g}}} \quad$ Average interior subchannel pressure drop, defined by $\mathrm{Eq} .(\mathrm{B}-4),(1 \mathrm{f} / \mathrm{sq} \cdot \mathrm{ft})$

$\Delta P_{\mathrm{s} 2} \quad$ Edge subchannel pressure drop (1bf/sq. ft) 
$\underline{\text { Page }}$

Abstract

Acknowledgements

Nomenclature

Iv

Table of Contents

vi.

Ltst of Figures

vii

List of Tables

v11i

Chapter 1

Introduction

Chapter 2

Experimental Apparatus

Chapter 3

Experimental Results

Chapter 4

Discusston of Results

4. 1

Bundle Average Priction Factors

4.2

Local Frletion Factors of Interior Subchannels

11

$4 \cdot 3$

Local Friction Factors of

12

Edge Subchannels

Chapter 5

Conclusions

$13 a$

Appendix A

List of Data

Appendix B

Error Analysis

53

References

60

F1gures

15

Tables

30 


\section{Elst of Figures}

Figure No.

$\underline{\text { Page }}$

$2-1$

Static Pressure Taps Location Scheme

$2-2$

Deslgn Conflguration of Instrumentation Rod

15

$3-1$

Static Pressures at $15^{\prime \prime}$ and $27^{\prime \prime}$ Below the

Exit Plane of the $4 "$ Lead Bundie

(Interior Subchannel)

$3-2$

Static Pressures at $15^{\text {th }}$ and $27^{\prime \prime}$ Below the

Exit Plane of the 4 "Lead Bundle

(Edge Subchannel)

3-3 Stat1c Pressures at 16.1" and 30.1" Below

the Extt Plane of the $2^{\prime \prime}$ Lead Bundle (Interior Subchannel)

Static Pressures at $16.1^{\text {" }}$ and $30.1^{\prime \prime}$ Below the Exit Plane of the 2" Lead Bundle (Edge Subchannel)

3-5 Pressure Drop Data of an Interior Subchannel 20 in the 4" Lead Bundle

3-6 Pressure Drop data of an Edge Subchannel in the 4" Lead Bundle

3-7 Pressure Drop Data of an Interlor Subchannel 22 In the $2^{\text {" }}$ Lead Bundle

3-8 Pressure Drop Data of an Edge Subchannel In the $2^{\prime \prime}$ Lead Bundle

Bundle Average Friction Factor for the 4" Lead Bundle

$4-1$

Bundle Average Friction Factor for the 2" Lead Bundle

for the 4" Lead Bundle

4-4 Local Interior Subchannel Friction Factor for the 2" Lead Bundle

Local Edge Subchannel Friction Factor for the 4" Lead Bundle

$4-6$

Local Edge Subchannel Friction Factor for the 2" Lead Bundle 


\section{List of Tables}

Table No.

Page

2-1 Geometric Characteristics of the

3-1 List of Pressure Drop Data of Pressure

31 Taps and Instrumentation Rod 


\section{CHAPTER 1}

\section{INTRODUCTION}

The pressure drop experiment was performed in two LMFBR blanket bundles. One of the bundles has the geometric characteristics of $\frac{P}{D}=1.067$ and $\frac{H}{D}=8.0$ which are similar to those of the blanket assemblies currently designed for the Clinch River Breeder Reactor. The second bundle has ident1cal geomtric characteristics, except that its $\frac{H}{D}$ ratio is 4.0 .

The pressure drop data were taken in two subchannels: one, a center Interior subchannel and the other, a typical edge subchannel. The subchannel friction factors of the interior and edge subchannels and the bundle average friction factor are determined from the corresponding pressire drop data.

The main purpose of this experiment is to obta1n Information for the following hydraulic characteristics:

1) The pumping power required for the current CRBR blanket assemblies.

2) The lead length effect on the blanket bundle pressure drop.

3) The lead length effect on the local bubchannel friction factors for both interior and edge subchannels.

To date, there has been no data avallable to aid in the understanding of the aformentioned hydraulic characteristics for the blanket assemblies. The local subchannel friction 
factors for the wire wrapped hexagonal bundle are very important in determining the subcharnel flow rate pattern. These parameters have not yet been introduced into the study of the hydraulle behavior of a wlre-wrapped bundle. For these reasons, the experiment performed here ylelds fundamental information for LMFBR design practice. 
CHAPTER 2

EXPERIMENTAL APPARATUS

To obtain the pressure drop data, two static priessure measurements are taken at two separate elevations by either pressure taps or instrumentation rods. The pressure taps are located in the centers of the six faces of the hexagonal burile (as 1llustrated in Fig. (2-1)) to measure the edge subchannel static pressures. The Instrumentation rods are made up of two parts: a hollow tube with consecutive holes of 1/32 inch diameter, and an injector which can slide inside this hollow tube and align its end hole with the tube holes. The local pressure signal is transmitted through the tube holes and the end hole located at the end of the sliding inJector to a pressure gauge where the subchanneI static pressure can be quantitatively determined. The design configuration of this instrumentation rod 1 s 11 lustrated in Fig. (2-2). Notice that two palrs of o-rings are used in the end part of the alding rod to prevent the disturbance of the local static pressure signal from upstrean or downstream static pressures. Recirculation of the subchannel fluid in the gap between the sliding rod and the tube is prevented by enclosing this gap in neoprene tubing (as shown in F1g. (2-2)). The sliding rod can be aligned with the hole (on the tube) at which the static pressure w1ll be measured. Whth the ald of this instrumentation rod, the static pressure at different elevations can be determined. 
The geometric characteristics of the test bundle are listed In Table (2-1). Detailed bundle design conflgurations and the flow loop design scheme are given in Ref. (1). 
CHAPTER 3

EXPERIMENTAL RESULTS

A preliminary test is made to compare the static pressure arop data taken by two different types of instruments: pressure taps and Instrumentation rods located in the assembly peripheral region (as shown in Fig. $(3-1)$ ). The results show that there is practically no difference between these two sets of data (Table (3-1) lists these two sets of data for comparison). For this reason, the edge subchannel pressure drop data are obtalned in this experiment with the edge instrumentation rod. For the static pressure drop data of the interior subchannels, an Instrumentation rod $1 \mathrm{~s}$ placed at the center of the bundle to measure the static pressure at two different elevations. These measurements are taken at 15 inches and 27 Inches below the bundle exit plane, for both interior and edge subchannels of the four inch lead length bundle. The results are illustrated in Figs. (3-1) and $(3-2)$. For the two inch lead length bundle the static pressure data for both interior and edge subchannels are obtained at 16.1 inches and 31.1 Inches below the bundle exit plane. The results are iliustrated in Figs. (3-3) and (3-4) respectively. The raw data for the above four figures are documented in Appendix $\mathrm{A}$.

The pressure drop data, as a function of the Reynolds number, can be determined for the interlor and edge subchannels of the four and two inch lead length bundles from the gbove data. The pressure drop data of the two inch lead length 
bundle are illustrated in Figures (3-5) and (3-6) for interior and edge subchannels respectively. The pressure drop data of the four inch lead length bundle are lllustrated in Figures (3-7) and (3-8) for 1nterior and edge subchannels respectively. It should be noted that the pressure drop data obtained in this experiment taken on different days or by different laboratory assiștants under the same nominal operating conditlons are found always within the error bars presented together with the data. 


\section{CHAPTER 4 \\ DISCUSSION OF RESULTS}

The three parameters which are calculated from the experimental static pressure data w1ll be discussed below. First, the average bundle friction factors are calculated and discussed in Sect. (4-1). Secondly, the local frlction factors for the 1nterior subchannels of both bundles are calculated and discussed in sect. (4-2). Finaliy, the local friction factors for the edge subchannels of both bundles are calculated and discussed in Sect. (4-3).

\subsection{Bundle Average Friction Pactors}

The relationship between the bundle static pressure drop and the bundle average friction factor is as follows:

$$
\Delta P_{b}=f_{b} \frac{L}{D e} \frac{\rho \bar{V}_{b}^{2}}{2 \bar{g}_{c}}
$$

where $\Delta P_{b}=$ bundle average pressure drop over subchannel length $L$

$f_{b}=$ bundle average friction factor

De = bundle average equivalent hydraulic diameter

- fluta density

$v_{b}=$ bundle average velocity.

From the above formula, the bundle average friction factor can be reduced provided that $\Delta \mathrm{P}_{\mathrm{b}}$ is known. In this experiment, $\Delta P_{\mathrm{b}}$ is simply determined by averaging the 
the pressure drop data for interior and edge subchannel as follows:

$$
\Delta P_{b}=\frac{N_{1} A_{1} \Delta P_{1}+\Delta P_{2} A_{2} N_{2}}{N_{1} A_{1}+N_{2} A_{2}}
$$

where $\mathrm{N}_{1}=$ number of 1nterior subchannels

$\mathrm{N}_{2}=$ number of edge subchannels.

It should be noted that the $\Delta \mathrm{P}_{b}$ can be determined by a force balance in the following way:

$$
\Delta \mathrm{P}_{\mathrm{b}}=\frac{\sum_{1 \text { subchannel }}^{N} \Delta \mathrm{P}_{1} A_{1}}{A_{\mathrm{b}}}
$$

where $\Delta \mathrm{P}_{1}=$ pressure drop for subchannel 1

$$
\begin{aligned}
& A_{1}=\text { area for subchannel } 1 \\
& A_{b}=\text { total bundle area } \\
& N=\text { total number of subchannels }
\end{aligned}
$$

provlded the pressure drop data are avallable for all the subchannels over a certain subchannel-length. The simplification made in $\mathrm{Eq} .(4-2)$ is based on the assumption of constant static pressure drops for all the interlor subchannels and constant static pressure drops for all the edge subchannels. However, since the static pressure drop for an interlor subchannel is very close in magnitude to that for an edge subchannel (within $56 \%$ difference as can be observed by comparing Figs. (3-5) with (3-6), and (3-7) with (3-8)), the slmplification made in Eq. (4-2) will not 1nvolve a large error in the determination of $\triangle P_{b}$. From Eqs.(4-1) and (4-2), the bundle average friction factor can be calculated from the data presented in chapter 3 . 
F1gure (4-1) shows the calculated bunde average friction factor for the four inch lead length bundle, Figure (4-2) shows the calculated bundle average friction factor for the two inch lead length bundle. In these two figures, Rehme's correlation (Ref. 2) and Novendstern's correlation (Ref. 3) are plotted against the data for comparison.

It can be concluded from these two flgures that

1) In the high turbulent flow reglme, i.e., Re > 7000, the bundle average friction factors are proportional to $\mathrm{Re}^{-0.25}$ for both two and four Inch lead bundles. These two bundle average friction factors are characterized by the following two formulas:

$$
\begin{aligned}
& f_{b}=\frac{0.48}{R e^{0.25}} \text { for the four inch lead bundle } \\
& f_{b}=\frac{0.9}{R e^{0.25}} \text { for the two inch lead bundle }
\end{aligned}
$$

2) The friction factors become inversely proportional to the Reynolds number in the flow regime below Re $=500$ for both bundles. These laminar bundle average friction factors are characterized as:

$$
\begin{aligned}
& f_{b}=\frac{90}{k e} \text { for the four inch lead bundle } \\
& f_{b}=\frac{160}{k e} \text { for the two inch lead bundle }
\end{aligned}
$$

3) In the flow regime with Re between 500 and 7000 the bundle average friction factors possess the characteristics of both the high turbulent and the pure laminar flow 
regige bundle average friction factors. In other words, the bundle average friction factors are proportional to $R e^{-n}$, where $n$ is a number between 0.25 and 1.0 .

4) Novendstern's correlation predicts bundle average friction factors which are higher than those obtalned experimentally for both two and four inch lead bundles. The difference in Novendstern's results and the experiment results is explained by noting the applicable range for Novendstern's correlation with the experimental geometric condition. Since the geometric conditions for the two Inch lead bundle are outstde the applicable range of rod dlameter and the $\frac{H}{D}$ ratio, and for the four inch lead bundle, are outside the applicable range of rod diameter, a difference in results should be expected.

5) Rehme's correlation predicts the bundle average friction factors wh1ch are lower than those obtalned in this expertiment for both two and four inch lead bundies. The reason for the affference between the predictions of the correlation and the experimental results is that the correlation was determined for the $\frac{P}{\bar{D}}$ ratios of 1.125 to 1.417. The error bar 1llustrated in Figs. (4-1) and (4-2) Is the maximum expected error inherent in the determination of the bundle average friction factors. The deviation of this maximum expected error is given in Appendix B. 


\subsection{Local Friction Factors of Interior Subchannels}

The local.friction factor is related to the subchannel

pressure drop as follows:

$$
\Delta P_{s}=f_{s} \frac{L}{D e_{t}} \frac{\rho V^{2}}{?}
$$

where $\Delta \mathrm{P}_{\mathrm{g}}=$ subchannel pressure drop for elther interior or edge subchanne?

$$
\begin{aligned}
& f_{s}= \text { local subchamel friction ractor } \\
& \text { Des= subchannel equivalent hydraulic diameter } \\
& v_{s}= \text { subchannel average velocity (over one lead } \\
& \text { length) }
\end{aligned}
$$

The parameter $\Delta P_{s}$ is measured in this experiment and the parameter $v_{s}$ is determined by the flow split parameters $x_{l}$ and $x_{2}$ (Ref. 4), defined as the ratios of the average interior subchannel velocity to the bundle ayerage velocity, measured in both two inch and four lnch lead bundles. By lising the above equation and the measured parameters $\Delta \mathrm{P}_{\mathrm{s}}$ (interior subchannel pressure drop) and $x_{1}$, we can calculate the local subchannel friction factors of the interior subchannels for both two and four finch lead bundles. The calculation results are 1llustrated in Figs. (4-3) and (4-4) for the four and two inch lead bundies respectively. It should be noted that in these two figures the local 1nterior subchannel friction factors are plotted against the local Interior subchannel Reynolds number, whlch is deftned as:

$$
\operatorname{Re}_{1}=\frac{\rho V_{1} D e_{1}}{\mu}
$$




$$
\begin{aligned}
& \text { where } \mathrm{V}_{1}= \\
& \text { De }=\text { Interior subchannel average velocity }=x_{1} v_{b} \\
& \\
& \text { diameter. }
\end{aligned}
$$

From the above two figures, the following hydraulic characteristics are observed for the local interior subchannel friction factors:

1) In the high turoulent flow regime, 1.e., Re $>7000$, the local interior subchannel friction factors are proportional to $\mathrm{Re}_{1}^{-0.25}$ for both two and four inch bundles. These two interior subchannel turbulent friction factors are characterized by the following formulas:

$r_{\text {s1 }}=\frac{0.593}{\mathrm{Re}_{1}{ }^{0.25}}$ for the rour inch lead bundle

$f_{s_{1}}=\frac{1.27}{\operatorname{Re}_{1} 0.25}$ for the two inch lead bundle

2) The local interior subchannel friction factor for the two inch lead bundle is larger than that for the four inch lead bundle throughout the Reynolds number range under investigation.

\subsection{Local Friction Factors of Edge Subchannels}

The local friction factors of the edge subchannels are calculated according to $\mathrm{Eq}$. (4-8) by employing the edge subchannel pressure drop data obtalned in this experiment and the edge subchannel flow split parameters $x_{2}$ reported in Ref. (4) for both two and four inch lead bundles. The results 
are illustrated in Figs. (4-5) and (4-6) for the four and two inch lead bundies. In these two figures, $\mathrm{f}_{\mathrm{s} 2}$ (local edge subchannel friction factor) is plotted agalnst the local edge subchannel Reynolds number whtch is defined as:

$$
\operatorname{Re}_{2}=\frac{D \pm}{D} \frac{D e_{2}}{4} \text {. }
$$

The maximum expected errors illustrated in the above figures as error bars are derlved in Appendix $B$.

Fron the above two figures, we can observe the following hydratile characteristics:

1) In the h1gh turbulent flow reglme, 1.e., $R e_{2}>7000$, the local edge subchannel friction factors are proportional to $\mathrm{Re}_{2}^{-0.25}$ for both two and four inch lead bundles. These two sets of the local edge subchannel friction factor results are correlated:

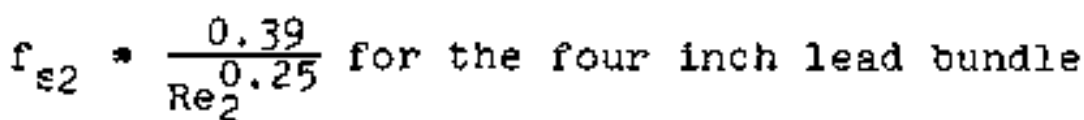

$f_{s 2}=\frac{0.6}{R_{2}^{0.25}}$ for the tiro inch lead bundle

Comparing these two formulas with Eqs. (4-10) and (4-11), we can conclude that the wire wrap lead length has a stronger effect on the interlor subchannel friction factor than on the edge subchannel friction factor.

2) The local edge subchannel friction factor for the two inch lead bundle 1 always larger than that for the four inch lead bundle. 
CHAPTER 5

CONCLUSION

The experiment results in this report has shown the following general characteristics concerning the bundle and subchannel friction factors of the test blanket mock-ups:

1. The turbulent friction factors either for two types of subchannels, i.e., edge and interior, or for the buntile as a whole are proportional to $R e^{-0.25}$.

2. The edge subchannel friction factors are considerably lower than the interior subchannel friction factors over the Reynolds number range from laminar flow to turbulent flow.

3. Current bundle friction factor correlations developed either by Novendstern or by Rheme be extended to the experimental results within the experimental error bar.

A subchannel pressure drop model which explain the above general characteristic (2) has been developed by $C$. Chiu et al, In Reference 5. This model considers the effect of the form drag, induced by the whe, and the transverse velocity between subchannels in the determination of the subchannel friction factor. Further work to extend thls model to predict the bundle average friction ractor is under way by c. Chiu and Kerry Basehore. 


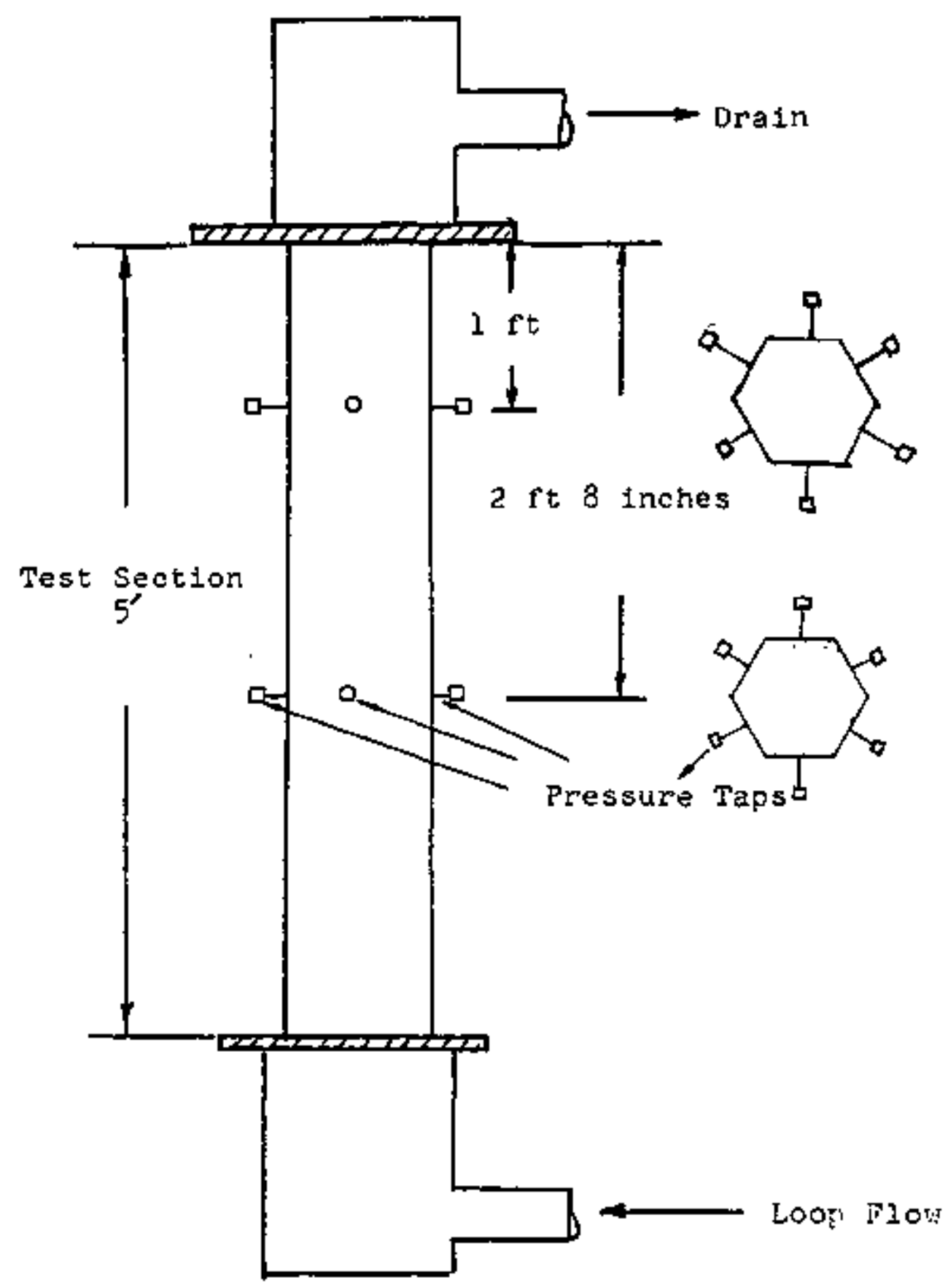

FIGtiRE 2-1 Stotic zossure Tap Location Scheme 


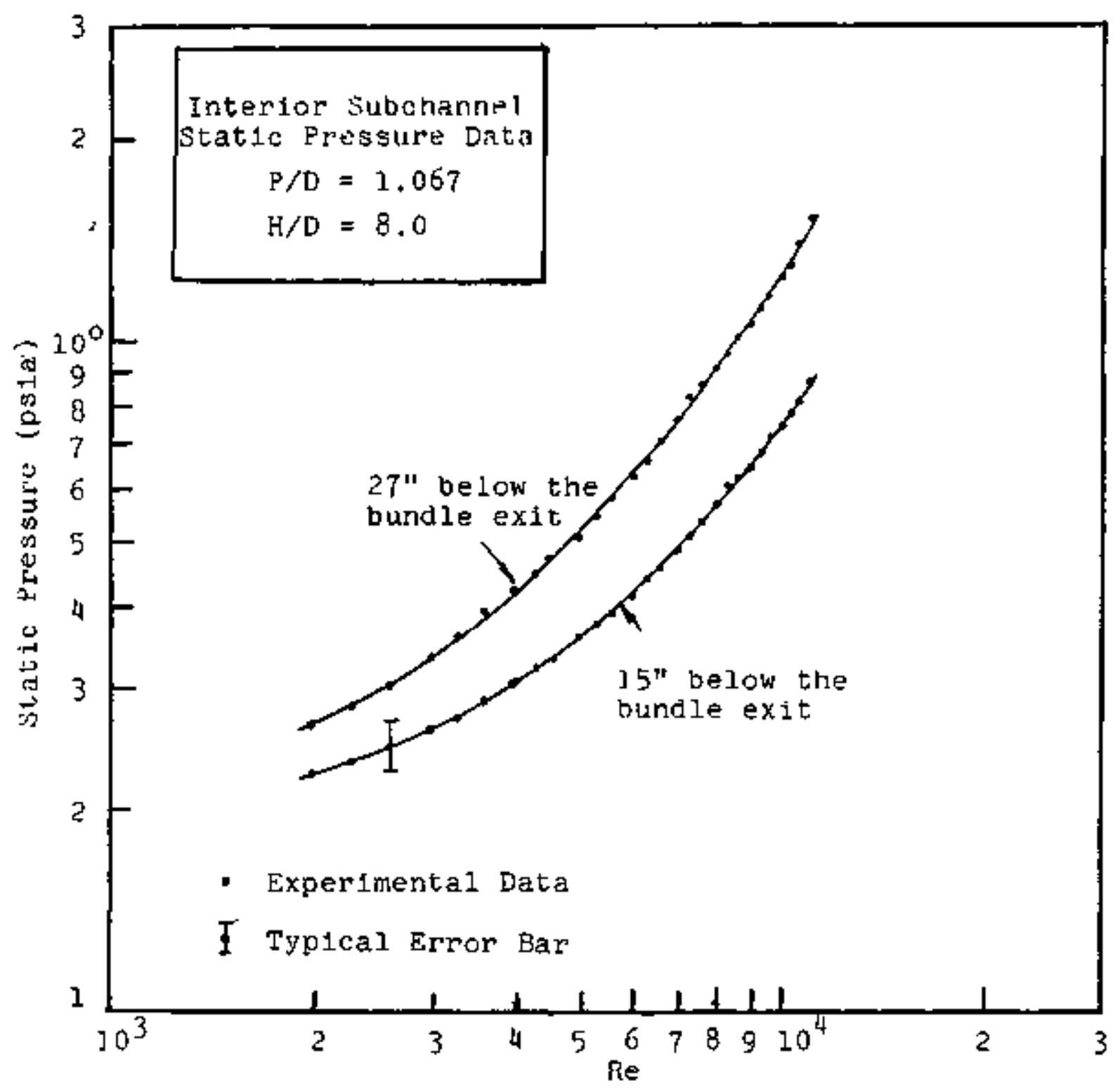

FIGURE 3-1 Static Pressures at 15" and 27" Below the Exit Plane of the $4^{+1}$ Lead Bundle (Interior Subchannel) 


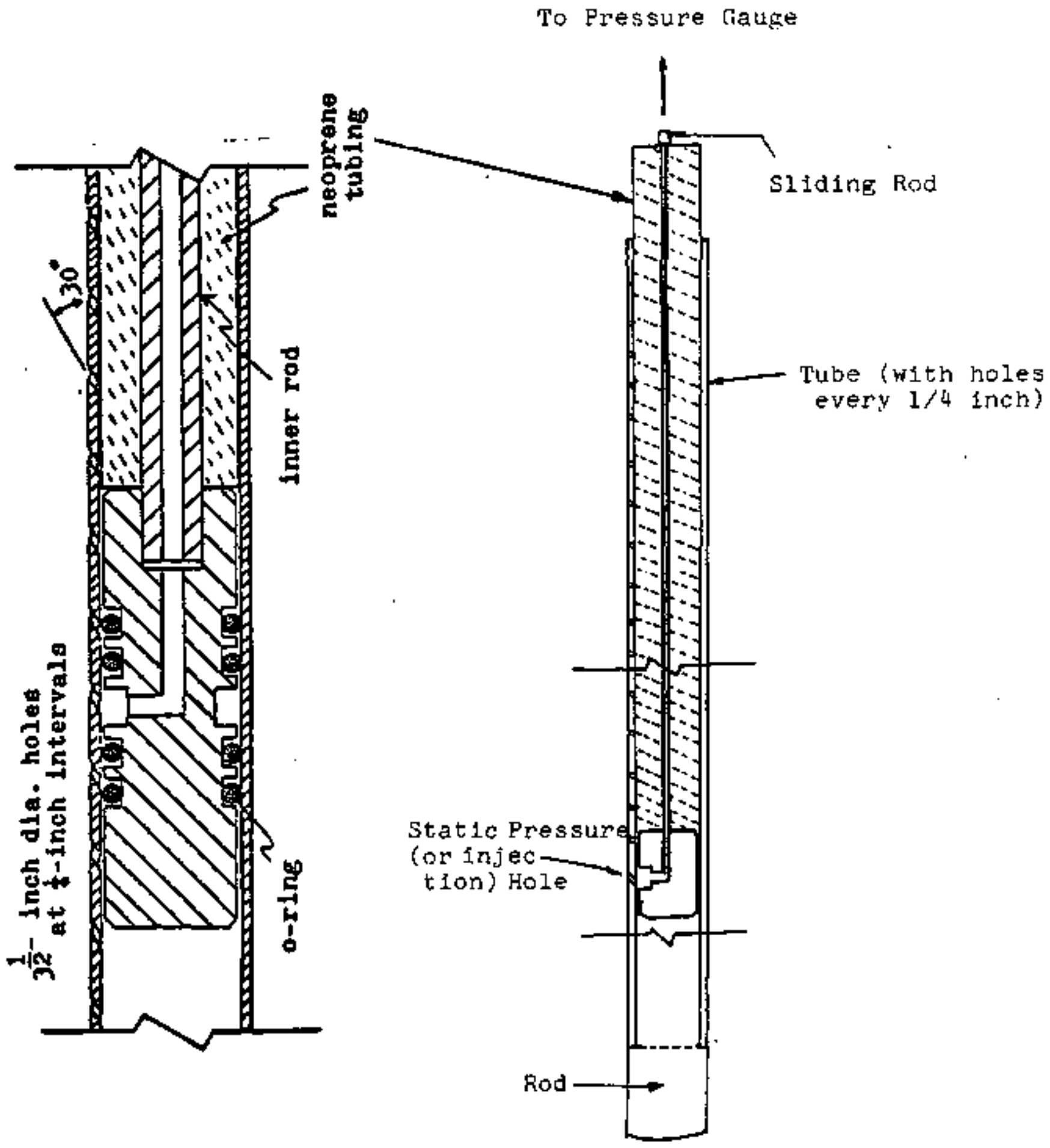

PIOURli 2.-2 Desipn Configuration of Instrumentation Rod 


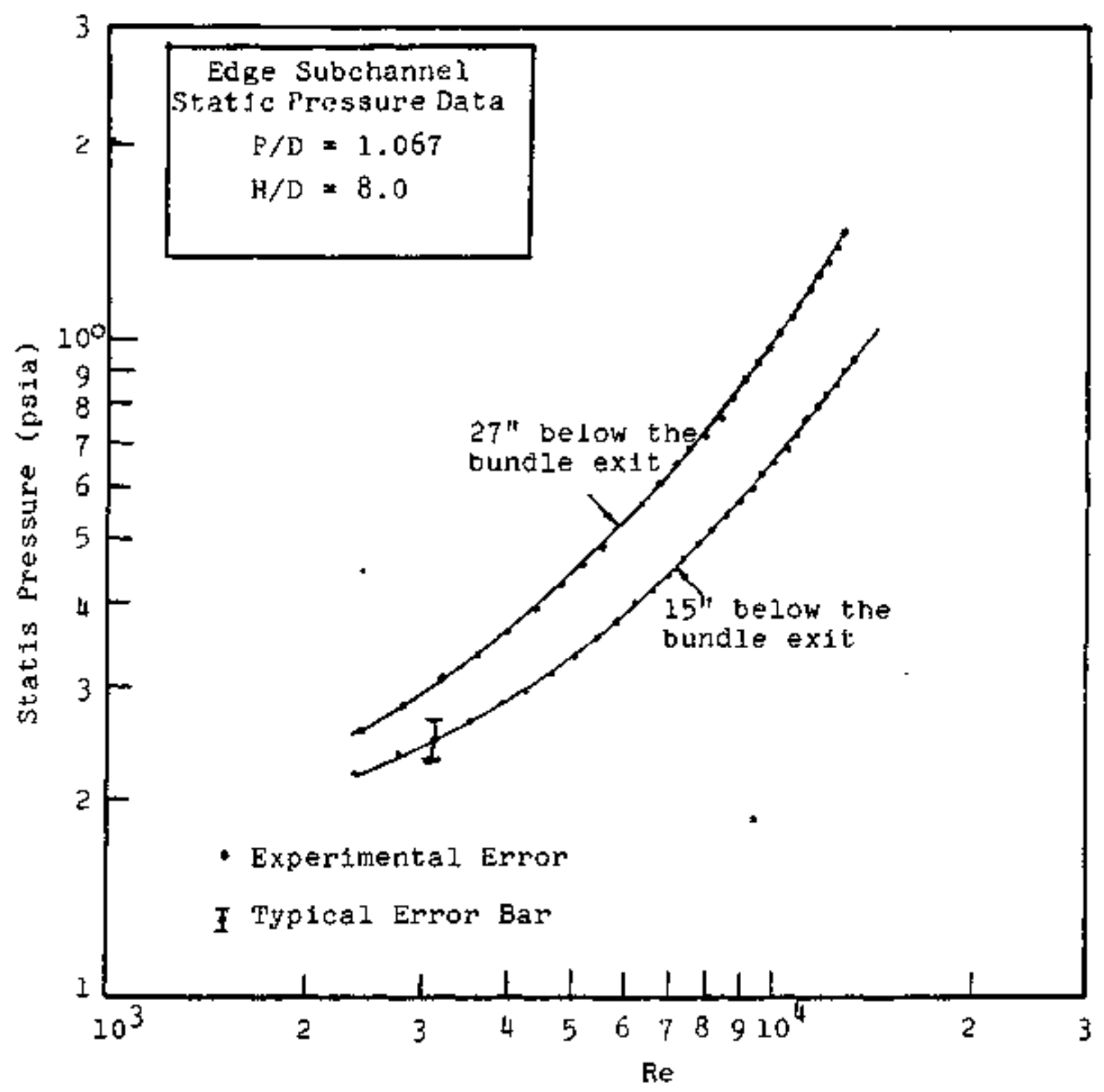

FIGURE 3-2 Stat1c Pressures at $15^{\prime \prime}$ and $27^{\text {th }}$ Below the Exit Plane of the 4" Lead Bundle (Edge Subchannel) 


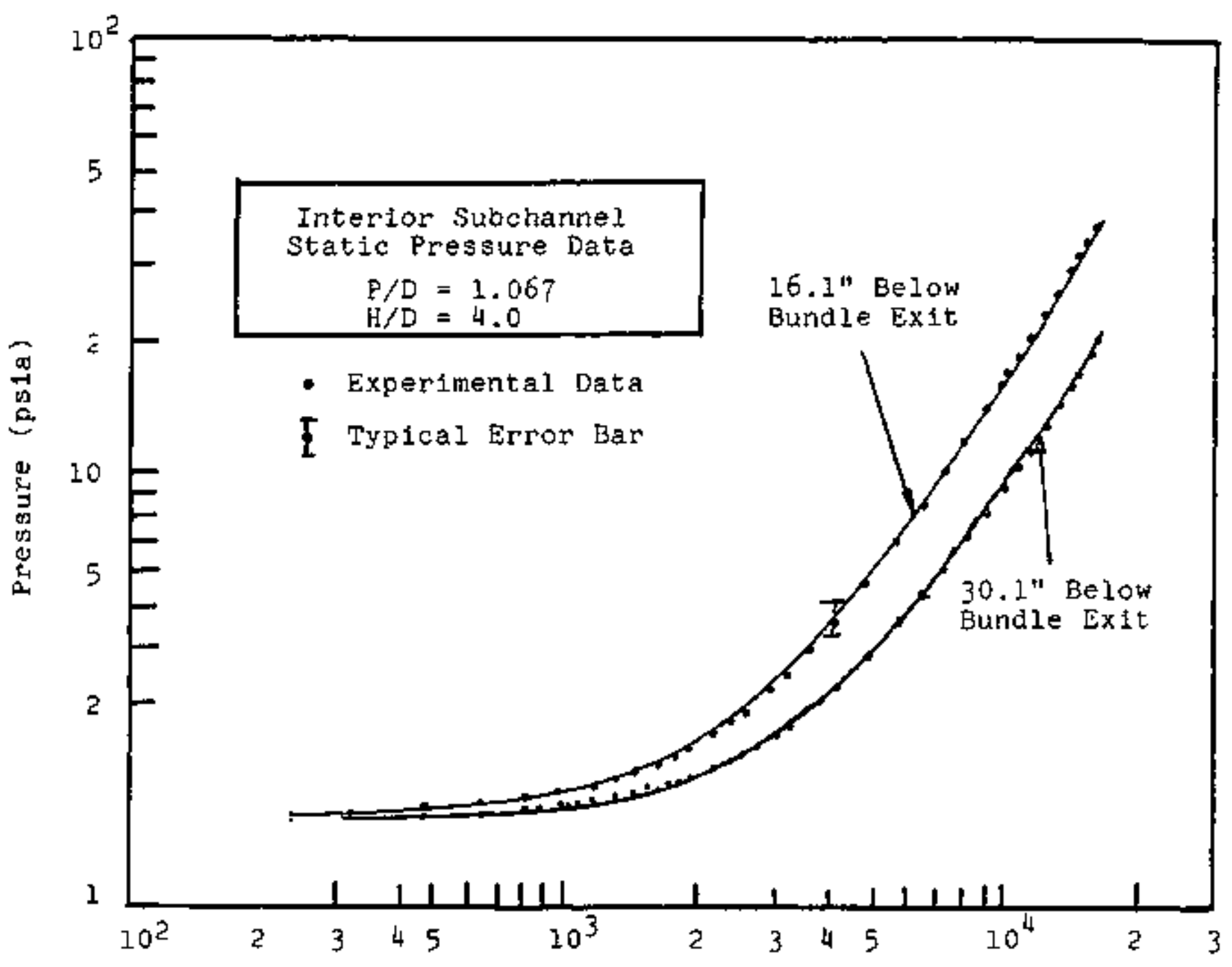

FIGURE 3-3 Static Pressures at 16.1" and 30.1" Below the Exit Plane of the $2^{\text {" }}$ Lead Bundle (Interior Subchannel) 


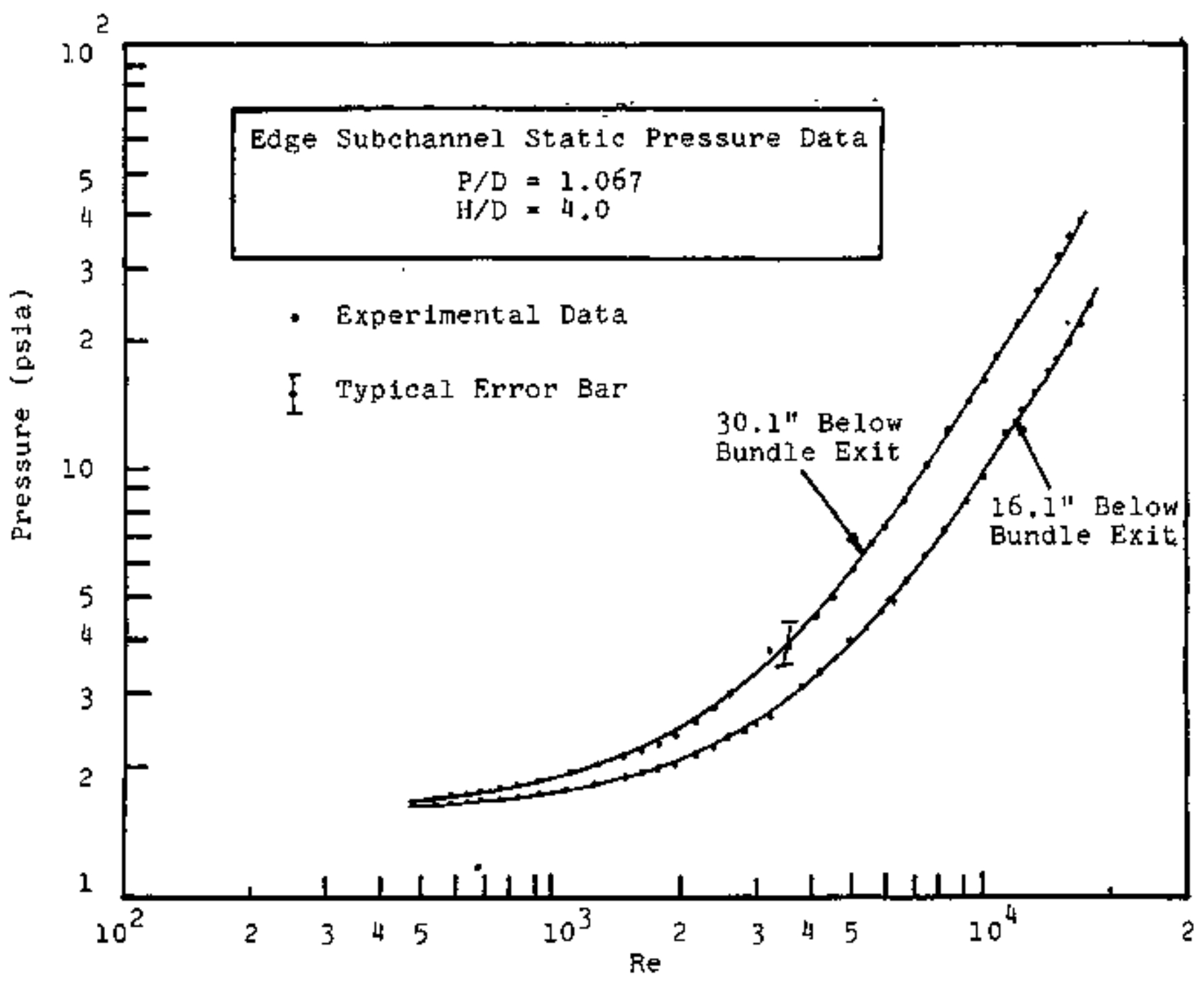

figure 3-4 Statis Pressures at $16.1^{\text {th }}$ and $30.1^{\dagger}$ Below the lixit Plane of the $2^{\prime \prime}$ Lead Bundle (Edge Subchannel) 


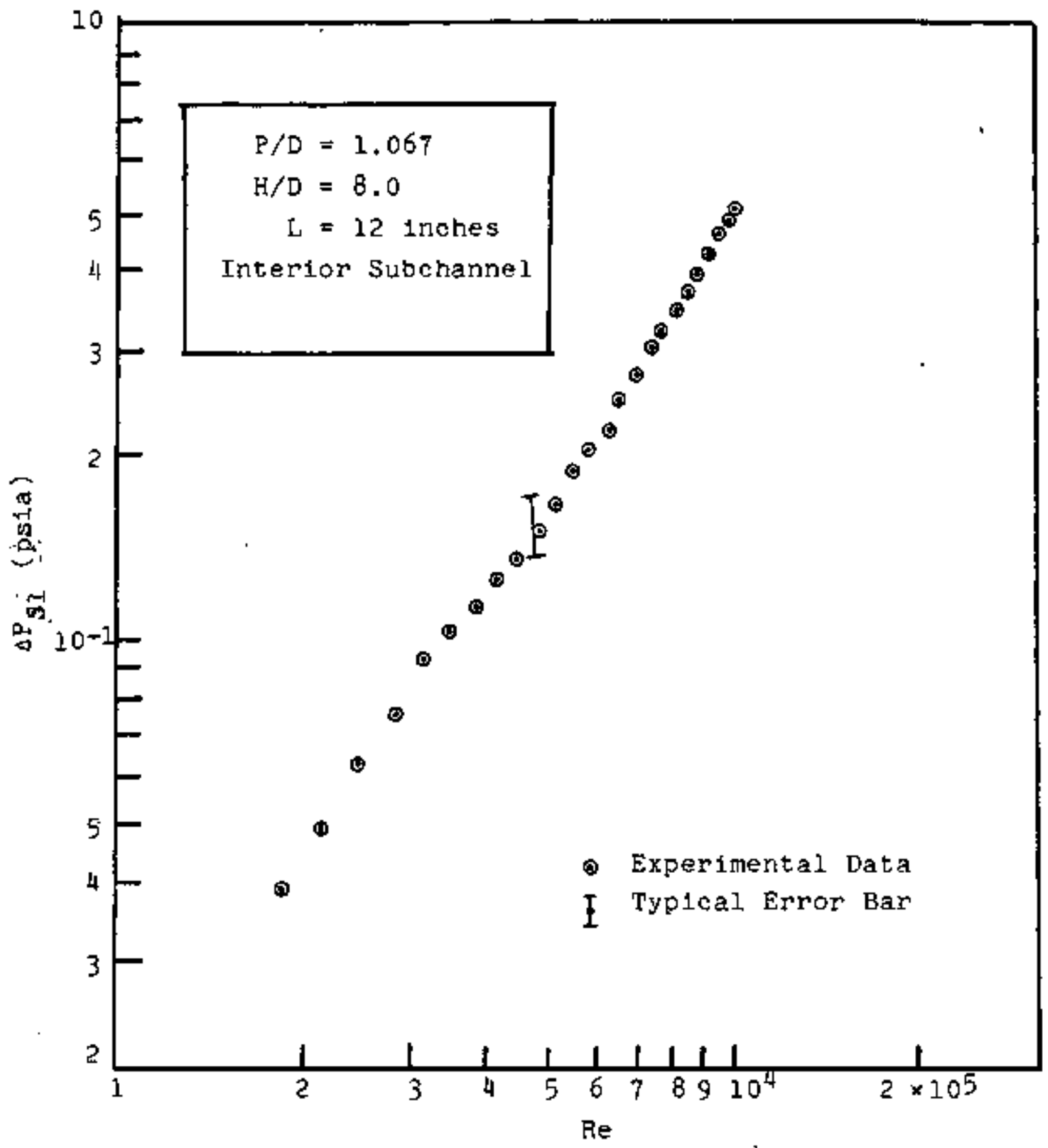

FIGURE 3-5 Pressure Drop Data of an Interior Subchannel in the 4" Lead Bundle 


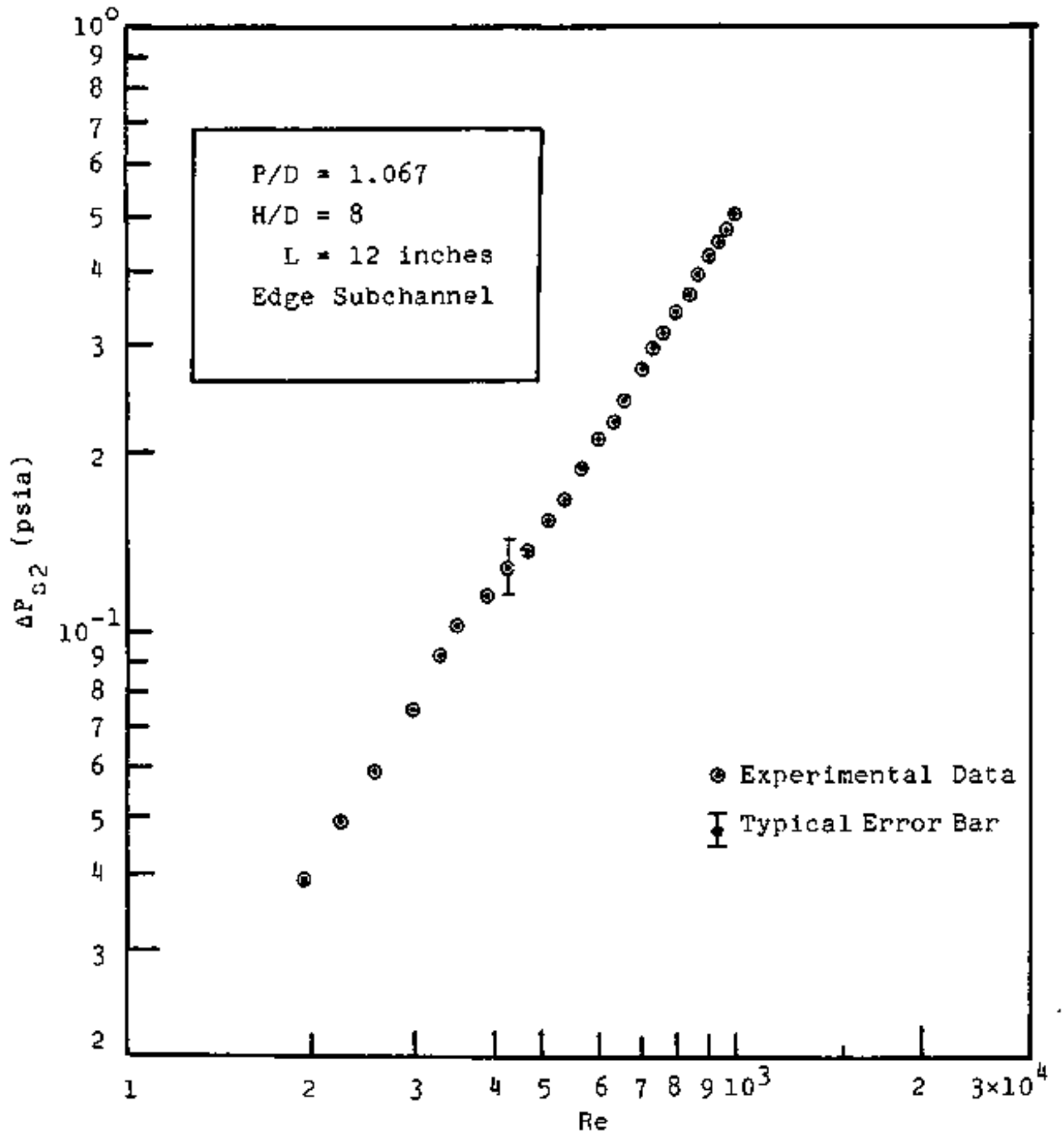

FIGURE 3-6 Pressure Drop Data of Edge Subchannel in the 4" Lead Bundle 


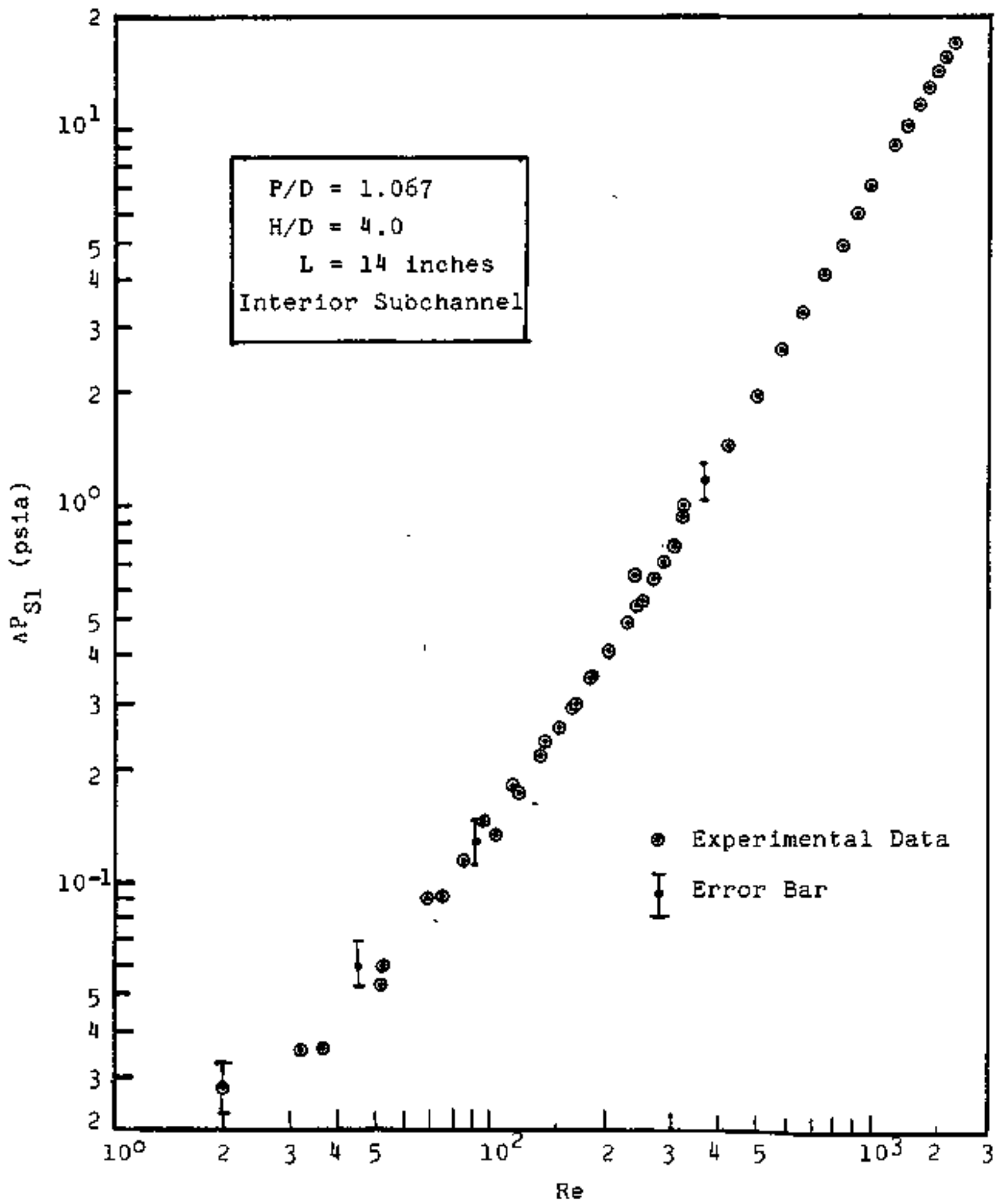

FIGURE 3-; Pressure Drop Data of an Interior Subchannel in the 2" Lead Bundle 


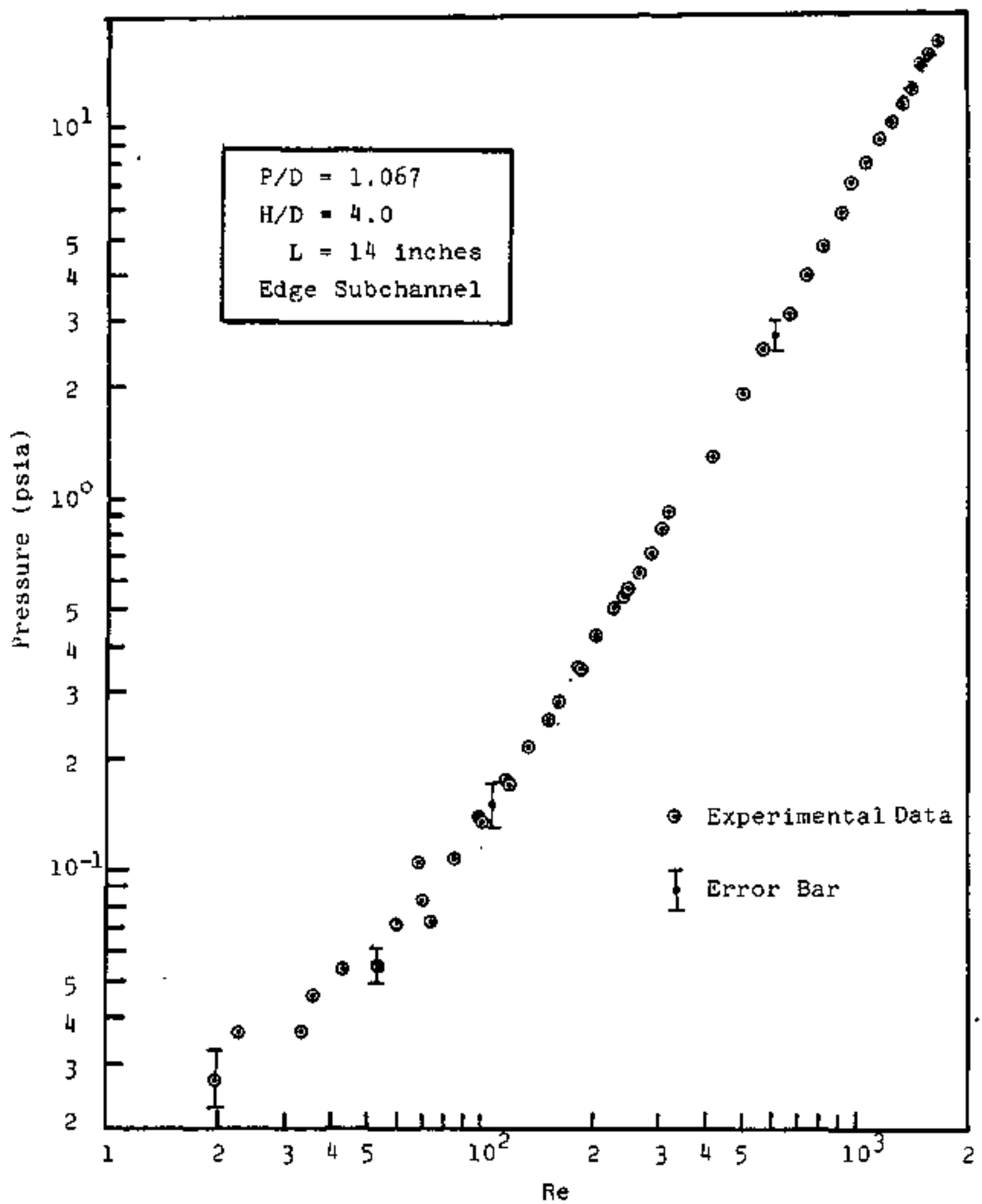

FIGURE 3-8 Pressure Drop Data of an Edge Subchannel in the 


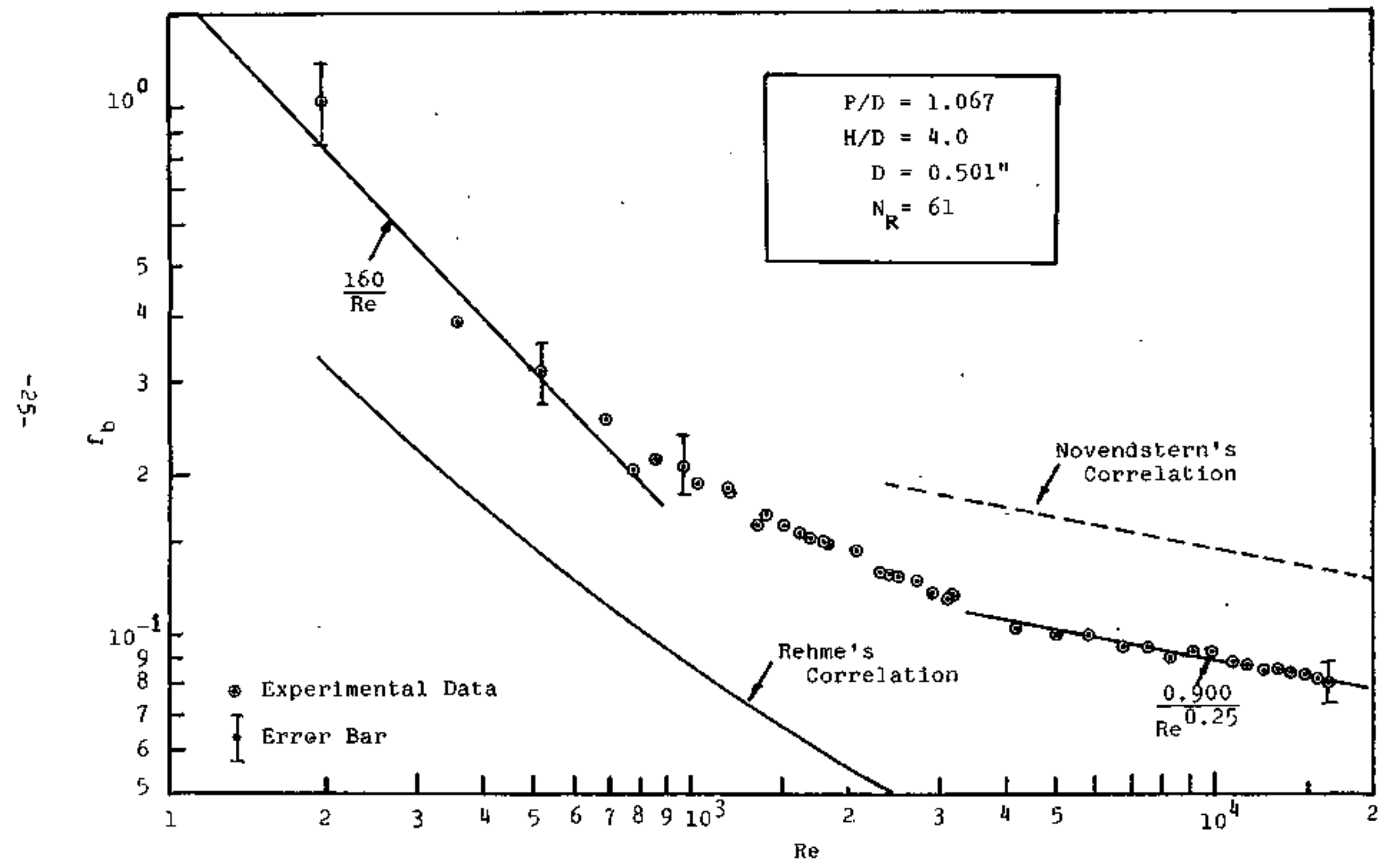

FIGURE 4-2 Bundle Average Friction Factor for the 2" Lead Bundle 


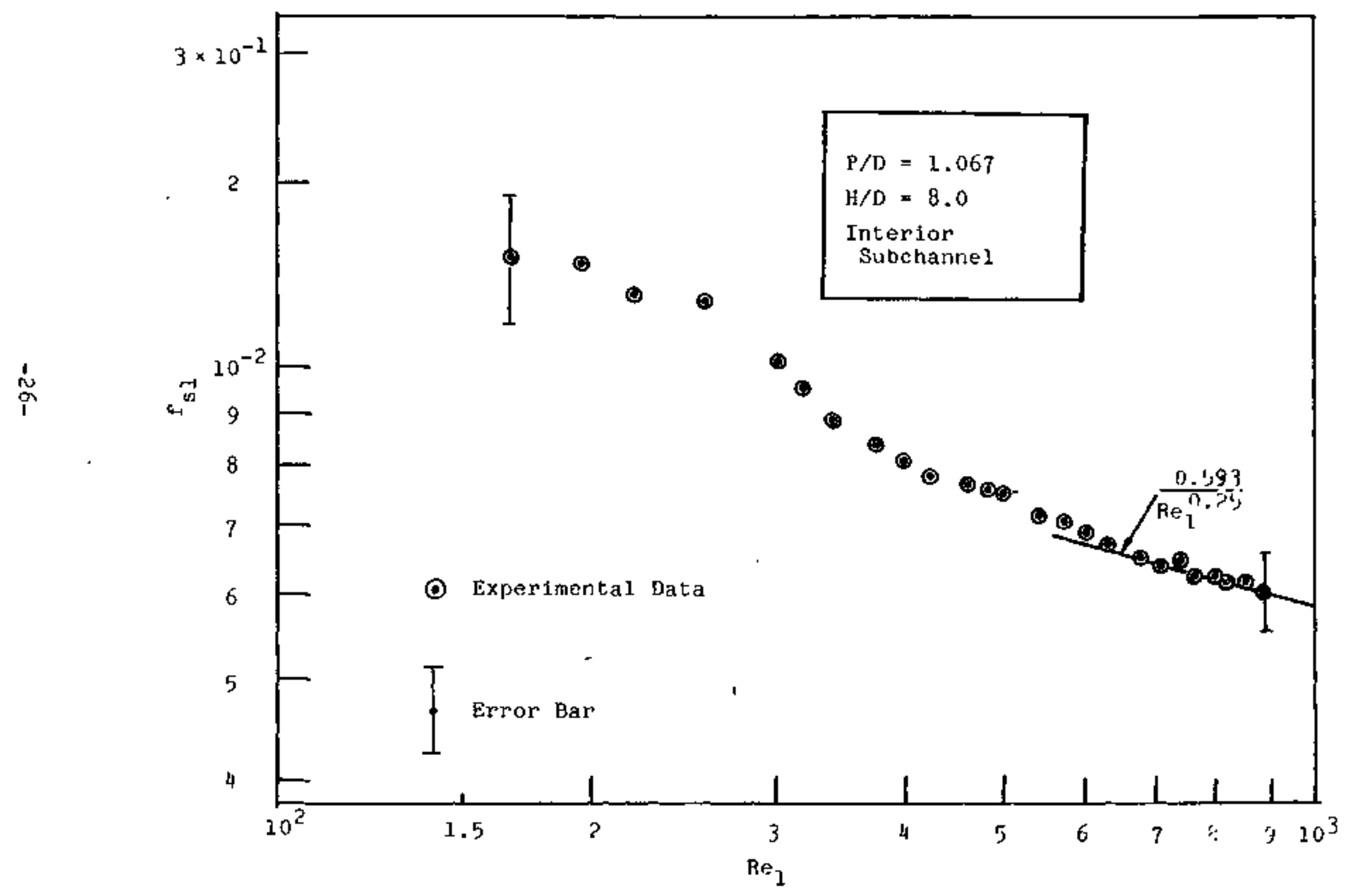

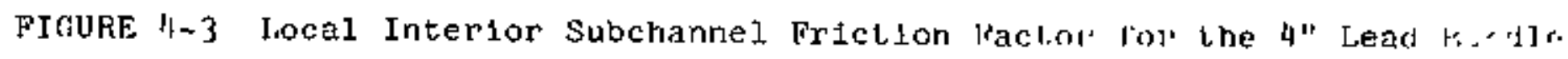




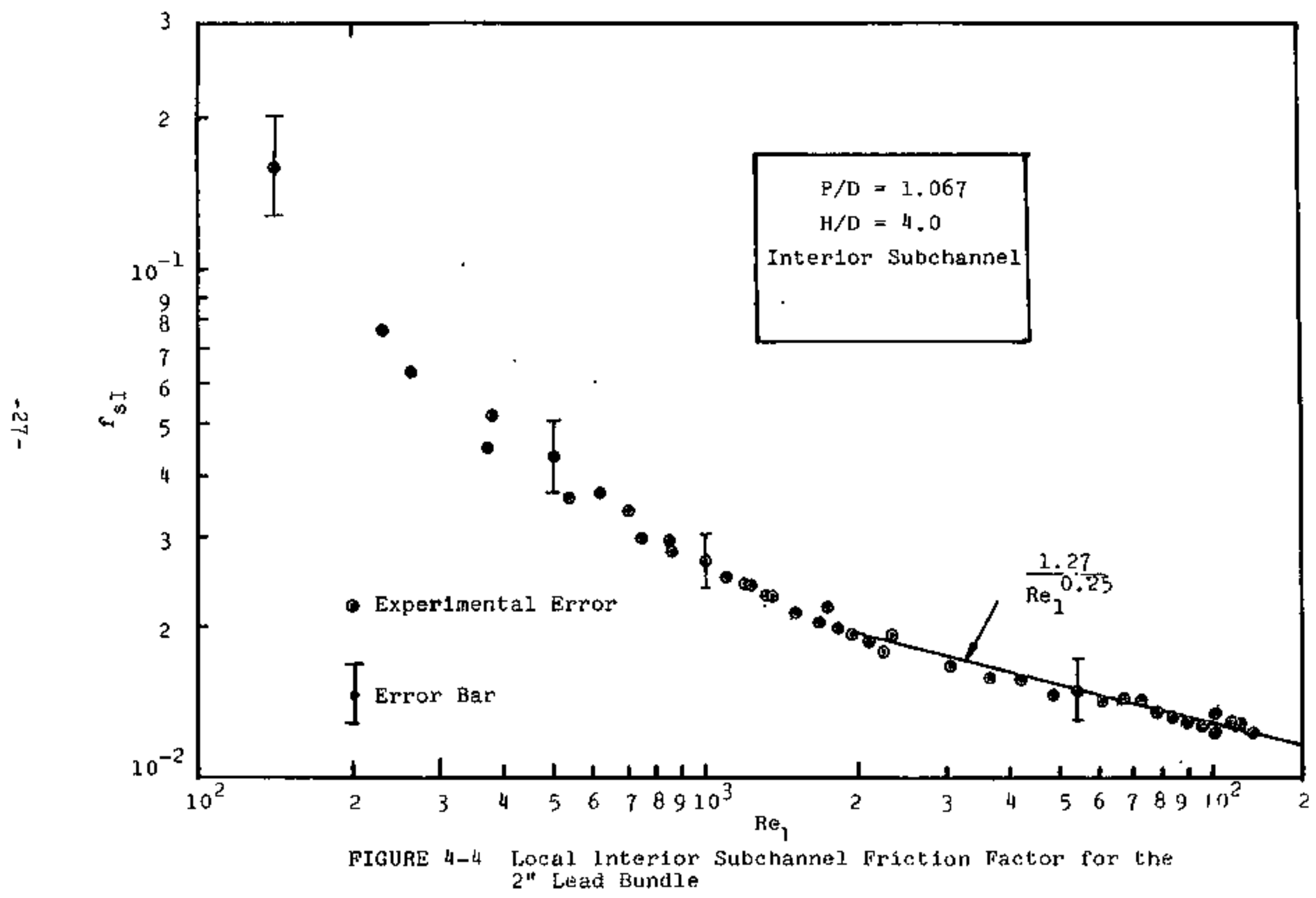




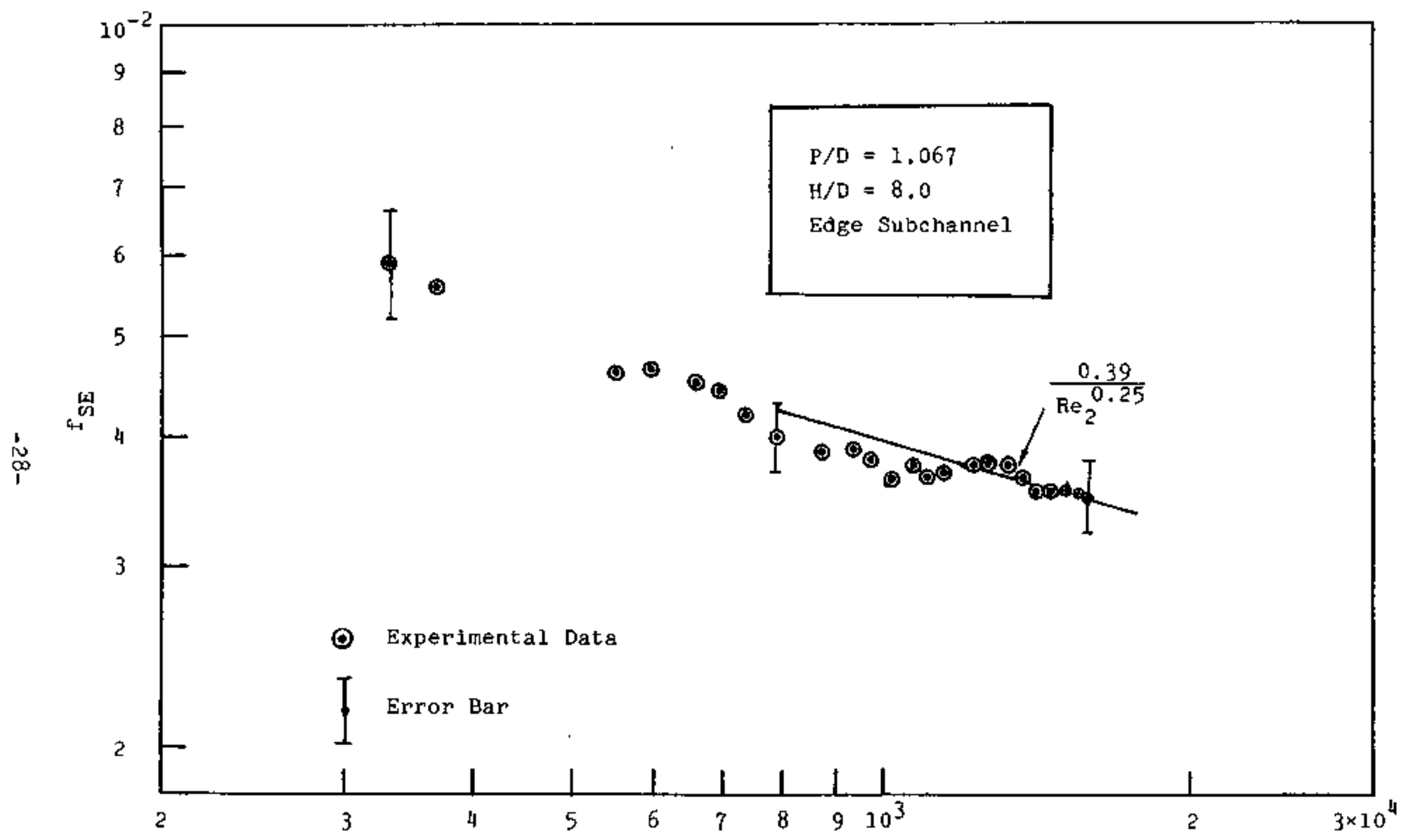

FIGURE 4-5 Local Edge Subchannel Friction Factor for the 4" Lead Bund1* 


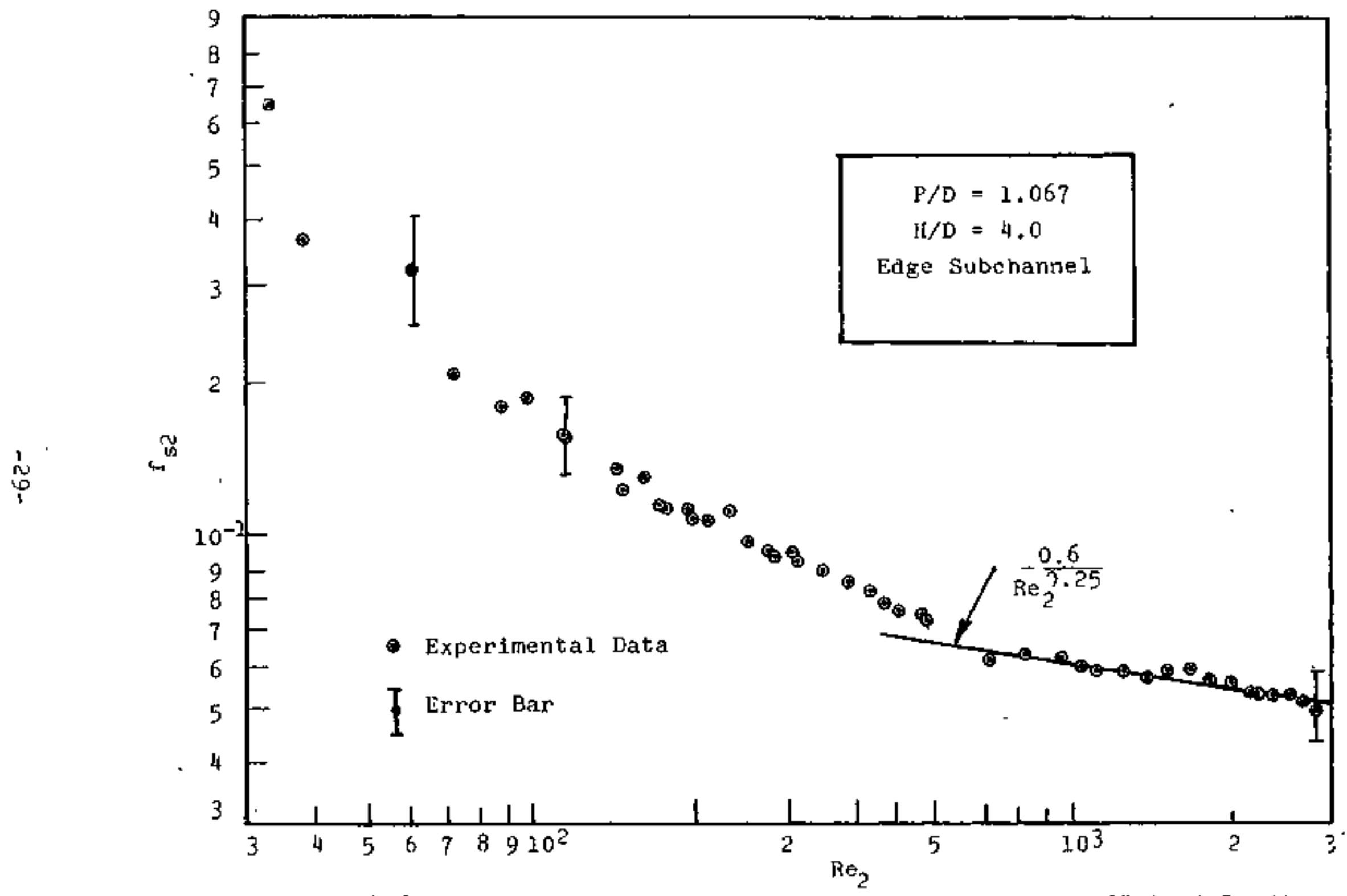

FIGURe 4-6 Local Edge Subchannej Prjetion Factor for the 2" Lead Bund:. 
TABLE 2-1

As-Bu1lt Test Bundle Geometric Parameters

\begin{tabular}{|l|l|}
\hline Bundle Length & 60 inches \\
\hline $\begin{array}{l}\text { Flat-to-Flat D1stance } \\
\text { (three difections) }\end{array}$ & 4.275 inches \\
\hline Rod Dlameter & 0.5011 inch \\
\hline Wire Diameter & 0.0314 \\
\hline Wire Wrap Lead & 4.0 inch \\
\hline $\begin{array}{l}\text { Face Wldth } \\
\text { (six faces) }\end{array}$ & 2.468 inches \\
\hline Average F-Factor & 0.820 \\
\hline
\end{tabular}


TABLE 3-1

List of Pressure Drop Data of Pressure Taps

and Instrumentation Rod (4" Wire Lead Bundle)

\begin{tabular}{|l|c|c|c|}
\hline Re & $\begin{array}{c}\Delta \mathrm{P}_{\text {tap }} \\
\left(\text { Inch of } \mathrm{H}_{2} \mathrm{O}\right)\end{array}$ & $\begin{array}{c}\Delta \mathrm{P}_{\text {Inst, Rod }} \\
\left(\text { inch of } \mathrm{H}_{2} \text { ) }\right.\end{array}$ & Difference $\%$ \\
\hline 470 & 3.87 & 3.80 & $1.8 \%$ \\
1100 & 7.92 & 8.15 & $2.8 \%$ \\
1900 & 16.2 & 16.0 & $1.25 \%$ \\
3300 & 40.8 & 41.0 & $0.5 \%$ \\
4600 & 64.9 & 65.1 & $0.3 \%$ \\
5600 & 85.17 & 86.7 & $1.76 \%$ \\
6300 & 101.8 & 102.1 & $0.3 \%$ \\
7300 & 131.9 & 133.1 & $1.0 \%$ \\
8300 & 163.7 & 163.0 & $0.4 \%$ \\
9300 & 196.7 & 197.0 & $0.1 \%$ \\
10000 & 220.45 & 222.3 & $1.85 \%$ \\
\hline
\end{tabular}

Wote : all the static Pressure data are measured in inch of water

${ }^{A P}$ tap $=\begin{aligned} & \text { Average Pressure Drop of Six Paces Measured } \\ & \text { by Pressure Taps }\end{aligned}$

Difierence $=\left|\frac{\Delta \mathrm{P}_{\text {tap }}-\Delta \mathrm{P}_{\text {Inst,Rod }}}{\Delta \mathrm{P}_{\text {Inst }, \text { Rod }}}\right|$ 
APPENDIX A

LIST OF DATA

$$
-32=
$$


TABLE A=1

STATIC PRESSURE DATA FOR THE TWO

INCH LEAD BUNDIE (INTERIOR SUBCHANNEL)

\begin{tabular}{|c|c|c|c|}
\hline GPM & $\mathrm{RE}$ & $P_{\text {static }}(30.1 ")$ & $P_{\text {stat } 1 c}\left(16.1^{\pi}\right)$ \\
\hline 3.70 & 197 & 1.69 & 1.66 \\
\hline 5.18 & 322 & 1.71 & 1.68 \\
\hline 5.55 & 362 & 1,72 & 1.69 \\
\hline 7.40 & 517 & 1.77 & 1.71 \\
\hline 7.40 & 528 & 1.77 & 1,71 \\
\hline 9.25 & 693 & 1.82 & 1.73 \\
\hline 10.0 & 744 & 1.86 & 1.77 \\
\hline 11.1 & 858 & 1.89 & 1.77 \\
\hline 12.6 & 972 & 1.95 & 1.80 \\
\hline 13.0 & 1030 & 1,95 & 1.81 \\
\hline 14.8 & 1170 & 2.06 & 1,88 \\
\hline 14.8 & 1190 & 2.02 & 1.85 \\
\hline 16.7 & 1360 & 2.11 & 1,90 \\
\hline 17.4 & 1390 & 2.17 & 1.93 \\
\hline 18.5 & 1520 & 2.20 & 1.95 \\
\hline 20.0 & 1630 & 2.29 & 2.00 \\
\hline
\end{tabular}


TABLE A.1 (cont ${ }^{\prime} \mathrm{d}$ )

\begin{tabular}{|c|c|c|c|}
\hline GPM & $\mathrm{RE}$ & $P_{\text {static }}\left(30.1^{\prime \prime}\right)$ & $\mathrm{P}_{\text {static }}\left(16.1^{\mathrm{N}}\right)$ \\
\hline 20.4 & 1690 & 2.28 & 1.98 \\
\hline 22.2 & 1810 & 2.42 & 2.08 \\
\hline 22,2 & 1850 & 2.39 & 2.05 \\
\hline 25.2 & 2080 & 2.60 & 2.18 \\
\hline 27.8 & 2300 & 2.76 & 2.27 \\
\hline 30 & 2400 & 3.07 & 2.42 \\
\hline 30.0 & 2500 & 2.92 & 2.35 \\
\hline 32,2 & 2690 & 3.07 & 2.42 \\
\hline 34.8 & 2880 & 3.25 & 2.54 \\
\hline 37.0 & 3110 & 3.43 & 2.65 \\
\hline 40 & 3200 & 3.84 & 2.84 \\
\hline 50 & 4200 & 4.85 & 3.39 \\
\hline 60 & 5000 & 6.01 & 4.06 \\
\hline 70 & 5800 & 7.36 & 4.76 \\
\hline 80 & 6700 & 8.81 & 5.59 \\
\hline 90 & 7500 & 10.5 & 6.42 \\
\hline
\end{tabular}


TABLE A-1 (cont'd)

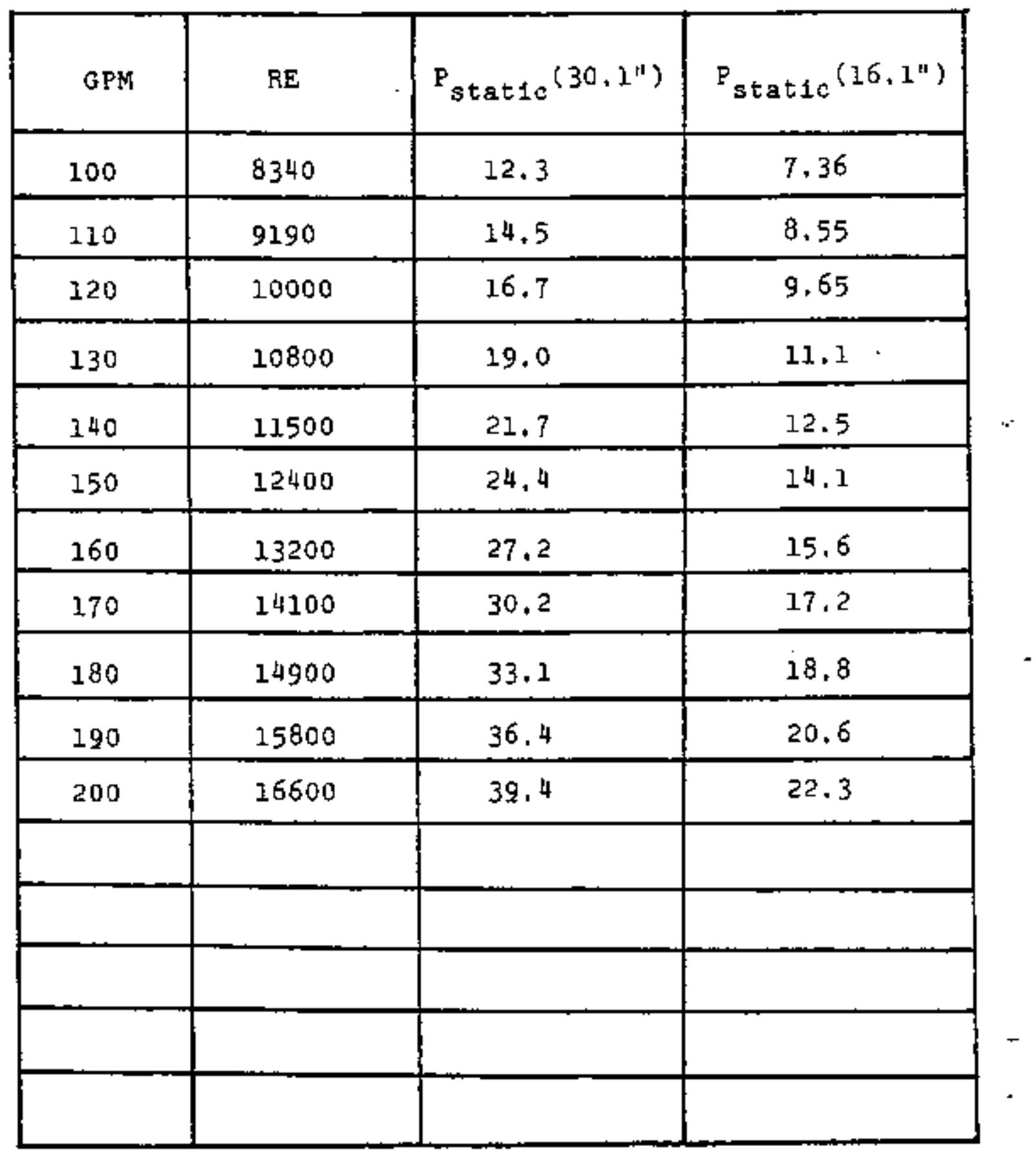


TABLE A.2

STATIC PRESSURE DATA FOR THE TWO *

INCH LEAD BUNDLE (EDGE SUBCHANNEL)

\begin{tabular}{|c|c|c|c|}
\hline GPM & $\mathrm{RE}$ & $P_{\text {static }}(30.1 ")$ & $P_{\text {static }}\left(16,1^{11}\right)$ \\
\hline 3.70 & 197 & 1.69 & 1.66 \\
\hline 4,44 & 227 & 1,61 & 1,52 \\
\hline 5.55 & 313 & 1,73 & 1.70 \\
\hline 5.55 & 362 & 1,72 & 1.68 . \\
\hline 7.03 & 428 & 1.71 & 1.77 \\
\hline 7.40 & 528 & 1.77 & 1.71 \\
\hline 0.14 & 591 & 1.80 & 1.73 \\
\hline 10.36 & 685 & 1.88 & 1.77 \\
\hline 9.25 & 693 & 1.81 & 1.73 \\
\hline 10.0 & 744 & 1,84 & 1.77 \\
\hline 11.1 & 858 & 1.88 & 1,77 \\
\hline 12.95 & 885 & 1,96 & 1,81 \\
\hline 12.6 & 972 & 1.95 & 1.80 \\
\hline 13.0 & 1030 & 1.94 & 1.80 \\
\hline 15.54 & 2086 & 2.08 & 1.88 \\
\hline 14.8 & 1170 & 2.04 & 1.86 \\
\hline
\end{tabular}


TABLE A-2 (cont'd)

\begin{tabular}{|c|c|c|c|}
\hline GPH & $\mathrm{RE}$ & $P_{\text {stattc }}\left(30,1^{\prime \prime}\right)$ & $P_{\text {static }}(16.1 ")$ \\
\hline 14.8 & 1190 & 2.01 & 1.84 \\
\hline 18.00 & 1276 & 2.21 & 1.95 \\
\hline 16.7 & 1360 & 2.09 & 3.88 \\
\hline 17.4 & 1390 & 2,17 & 1.91 \\
\hline 18.5 & 1520 & 2,18 & 1.93 \\
\hline 20.0 & 1630 & 2.27 & 1.98 \\
\hline 20.4 & 1690 & 2.27 & 1.98 \\
\hline 22.2 & 1810 & 2.42 & 2.06 \\
\hline 22.2 & 1850 & 2.36 & 2.02 \\
\hline 25.2 & $2080^{\circ}$ & 2.58 & 2.15 \\
\hline 27.8 & 2300 & 2.74 & 2.24 \\
\hline 30 & 2400 & 2.85 & 2,31 \\
\hline 30,0 & 2500 & 2.89 & 2,31 \\
\hline 32.2 & 2690 & 3,05 & 2.42 \\
\hline 34.8 & 2880 & 3.23 & 2.53 \\
\hline 37.0 & 3110 & 3.43 & 2,62 \\
\hline
\end{tabular}


TABLE A-2 (cont'd)

\begin{tabular}{|c|c|c|c|}
\hline GPM & RE & $P_{\text {static }}\left(30.1^{\prime \prime}\right)$ & $P_{\text {stat1c }}(16.14)$ \\
\hline 40 & 3200 & 3.64 & 2,71 \\
\hline 50 & 4200 & 4.55 & 3.25 \\
\hline 60 & 5000 & 5.77 & 3.86 \\
\hline 70 & 5800 & 7.11 & $4,58 \quad$ \\
\hline 90 & 3500 & 10,2 . & 6,24 \\
\hline 100 & 8340 & 12,0 & $7: 22$ \\
\hline 110 & 2120 & 14,1 & 8,16 \\
\hline 120 & 10000 & 16,3 & 9,20 \\
\hline 130 & 10800 & 18.6 & 10,4 \\
\hline 140 & 11500 & 21,0 & 11,7 \\
\hline 150 & 12400 & 23.4 & 13.1 \\
\hline 160 & 13200 & 26.3 & 14.7 \\
\hline 170 & 14100 & 29,2 & 16.3 \\
\hline 180 & 14900 & 32,3 & 17,8 \\
\hline 190 & 15800 & 35.1 & 19,4 \\
\hline 200 & 16600 & 37,5 & 20,6 \\
\hline
\end{tabular}


TABLE A -3

STATIC PRESSURE DATA FOR THE FOUR

INCH LEAD BUNDLE (INTERIOR SUBCHANNEL)

\begin{tabular}{|c|c|c|c|}
\hline GPM & RE & $\mathrm{P}_{\text {stat } 1 \mathrm{c}}\left(27^{\prime \prime}\right)$ & Pstatic $^{\left(15^{\circ}\right)}$ \\
\hline 30 & 2000 & 2.67 & 2.24 \\
\hline 35 & 2300 & 2.85 & 2.35 \\
\hline 40 & 2600 & 3,07 & 2.49 \\
\hline 45 & 3000 & 3.36 & 2.63 \\
\hline 50 & 3300 & 3.64 & 2,74 \\
\hline 55 & 3600 & 3.93 & 2.89 \\
\hline 60 & 4000 & 4.22 & 3.07 \\
\hline 65 & 4300 & 4.51 & 3.25 \\
\hline 70 & 4600 & 4,76 & 3.39 \\
\hline 75 & 5000 & 5.12 & 3.61 \\
\hline 80 & 5300 & 5.49 & 3.79 \\
\hline 85 & 5600 & 5.88 & 3.97 \\
\hline 90 & 6000 & 6.32 & 4.19 \\
\hline 95 & 6300 & 6.68 & 4.44 \\
\hline 100 & 6600 & 7.15 & 4.62 \\
\hline 105 & 7000 & 7.69 & 4.91 \\
\hline
\end{tabular}


TABLE $A-3$ (cont' $d$ )

\begin{tabular}{|c|c|c|c|}
\hline GPM & $\mathrm{RE}$ & ${ }^{P}$ static $\left(27^{\prime \prime}\right)$ & $P_{\text {static }}\left(15^{\prime \prime}\right)$ \\
\hline 110 & 7300 & 8,19 & 5.16 \\
\hline 115 & 7600 & 8,66 & 5.45 \\
\hline 120 & 8000 & 9.20 & 5.77 \\
\hline 125 & 8300 & 9.74 & 6.06 \\
\hline 130 & 8600 & 10,29 & 6.32 \\
\hline 135 & 9000 & 10.83 & 6.57 \\
\hline 140 & 9300 & 11.48 & 6.89 \\
\hline 145 & 9600 & 11.95 & 7.22 \\
\hline 150 & 10000 & 12.63 & 7.58 \\
\hline 155 & 10300 & 13.35 & 7.87 \\
\hline 160 & 10600 & 14.15 & 8.34 \\
\hline 165 & 11000 & 15.45 & 8,81 \\
\hline & & & \\
\hline & & & \\
\hline & & & \\
\hline & & & \\
\hline
\end{tabular}


TABLE A-4

STATIC FRESSURE DATA FOR THE FOUR INCH LEAD BUNDLE (EDGE SUBCHANNEL)

\begin{tabular}{|c|c|c|c|}
\hline GPM & $R E$ & $P_{\text {static }}\left(27^{\prime \prime}\right)$ & $P_{\text {stat } 1 c^{\left(15^{\prime \prime}\right)}}$ \\
\hline 30 & 2000 & 2.53 & 2.20 \\
\hline 35 & 2300 & 2.74 & 2.35 \\
\hline 40 & 2600 & 3.00 & 2.49 \\
\hline 45 & 3000 & 3.28 & 2.63 \\
\hline 50 & 3300 & 3.57 & 2.78 \\
\hline 55 & 3600 & 3.86 & 2.92 \\
\hline 60 & 4000 & 4.15 & 3.10 \\
\hline 65 & 4300 & 4,47 & 3.28 \\
\hline 70 &, 4600 & 4.76 & 3.54 \\
\hline 75 & 5000 & 5.20 & 3.72 \\
\hline 80 & 5300 & 5.52 & 3.97 \\
\hline 85 & 5600 & 5.92 & 4.15 \\
\hline 90 & 6000 & 6.35 & 4.37 \\
\hline 95 & 6300 & 6.68 & 4.62 \\
\hline 100 & 6600 & 7.00 & 4.84 \\
\hline 105 & 7000 & 7.47 & 5.09 \\
\hline
\end{tabular}


TABLE A-4 (cont $\left.{ }^{1} d\right)$

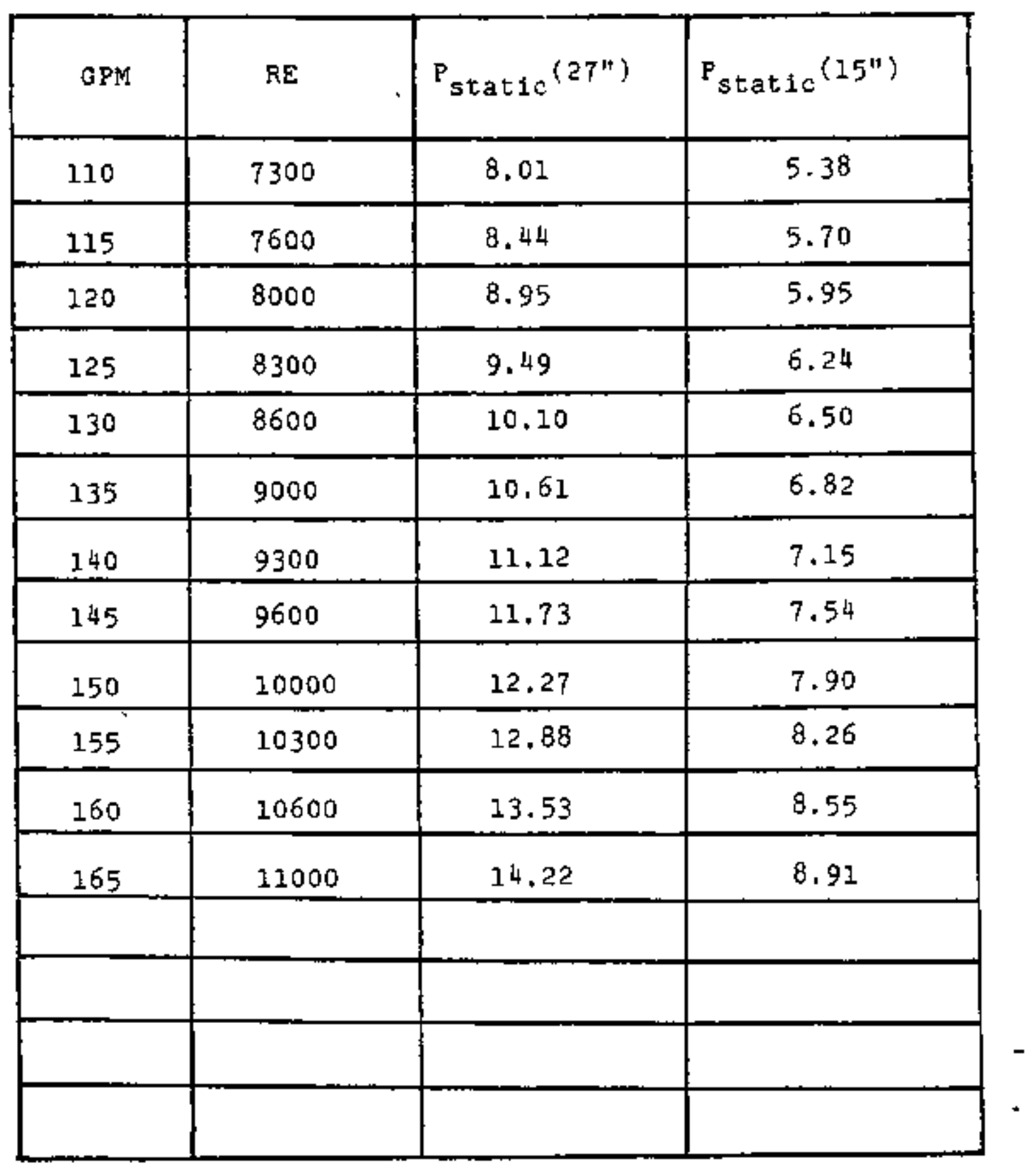


TABLE $A-5$

SUBCHANNEL PRESSURE DROP DATA FOR THE

TWO INCH LEAD BUNDLE (INTERIOR SUBCHANNEL)

\begin{tabular}{|c|c|c|}
\hline GPM & $\mathrm{RE}$ & $\Delta \mathrm{P}_{\mathrm{SI}}$ \\
\hline 3.70 & 197 & 0.0271 \\
\hline 5.18 & 322 & .0361 \\
\hline 5.55 & 362 & .0361 \\
\hline 7.40 & 517 &, 0541 \\
\hline 7.40 & 528 & .0632 \\
\hline 9.25 & 693 & .0902 \\
\hline 10.0 & 744 & .0902 \\
\hline 11.1 & 858 & .117 \\
\hline 12.6 & 972 & .144 \\
\hline 13.0 & 1030 & .135 \\
\hline 14,8 & 1170 & .180 \\
\hline 14.8 & 1190 & .171 \\
\hline 16.7 & 1360 & .208 \\
\hline 17.4 & 1390 & .235 \\
\hline 18.5 & 1520 & .253 \\
\hline 20.0 & 1630 & .289 \\
\hline 20.4 & 1690 & .298 \\
\hline
\end{tabular}


TABLE A-5 (cont'd)

\begin{tabular}{|c|c|c|}
\hline GPM & $\mathrm{RE}$ & $\Delta \mathrm{P}_{\mathrm{SI}}$ \\
\hline 22.2 & 1810 & .343 \\
\hline 22.2 & 1850 & .343 \\
\hline 25.2 & 2080 & .415 \\
\hline 27,8 & 2300 & .487 \\
\hline 30 & 2400 & .65 \\
\hline 30.0 & 2500 & .559 \\
\hline 32.2 & 2690 & .632 \\
\hline 34.8 & 2880 & .704 \\
\hline 37.0 & 3110 & .776 \\
\hline 40 & 3200 & 1,00 \\
\hline 50 & 4200 & 1,46 \\
\hline 60 & 5000 & 1.95 \\
\hline 70 & 5800 & 2.60 \\
\hline 80 & 6700 & 3.22 \\
\hline 90 & 7500 & 4,1 \\
\hline 100 & 8340 & 4.9 \\
\hline 110 & 9190 & 6.0 \\
\hline
\end{tabular}


TABLE A5 (cont'd)

\begin{tabular}{|l|l|l|}
\hline GPM & RE & ${ }^{A P} \mathrm{SI}$ \\
\hline 120 & 10000 & 7.1 \\
\hline 130 & 10800 & 7.9 \\
\hline 140 & 11500 & 9.2 \\
\hline 150 & 12400 & 10.3 \\
\hline 160 & 13200 & 11.6 \\
\hline 170 & 14100 & 13.0 \\
\hline 180 & 14900 & 14.3 \\
\hline 190 & 15800 & 15.8 \\
\hline 200 & 16600 & 17.1 \\
\hline & & \\
\hline & & \\
\hline & & \\
\hline
\end{tabular}


TABLE $A-6$

SUBCHANNEL PRESSURE DROP DATA FOR THE TWO INCH LEAD BUNDLE (EDGE SUBCHANNEL')

\begin{tabular}{|c|c|c|}
\hline GPM & $\mathrm{RE}$ & $\Delta \mathrm{F}_{\mathrm{SE}}$ \\
\hline 3.70 & 197 & 0.0271 \\
\hline 4.44 & 227 & .0361 \\
\hline 5.55 & 313 & .0361 \\
\hline 5.55 & 362 & .0451 \\
\hline 7.03 & 428 & .0541 \\
\hline 7.40 & 528 & .0541 \\
\hline 8.14 & $59 I$ & .0722 \\
\hline 10.36 & 685 & .108 \\
\hline 9.25 & 693 & .0812 \\
\hline 10.0 & 344 & .0722 \\
\hline 11.1 & 858 & .108 \\
\hline 12.95 & 885 & .144 \\
\hline 12.6 & 972 & .144 \\
\hline 13.0 & 1030 & .135 \\
\hline 15.54 & 1086 & .198 \\
\hline 14.8 & 1170 & .180 \\
\hline 14.8 & 1190 & .171 \\
\hline
\end{tabular}


TABEE A-6 (cont'd)

\begin{tabular}{|l|l|l|}
\hline GPM & RE & $\Delta \mathrm{P}_{\mathrm{SE}}$ \\
\hline 18.00 & 1276 & .262 \\
\hline 16.7 & 1360 & .217 \\
\hline 17.4 & 1390 & .253 \\
\hline 18.5 & 1520 & .253 \\
\hline 20.0 & 1630 & .289 \\
\hline 20.4 & 1690 & .298 \\
\hline 22.2 & 1810 & .361 \\
\hline 22.2 & 1850 & .343 \\
\hline 25.2 & 2080 & .433 \\
\hline 27.8 & 2300 & .505 \\
\hline 30 & 2400 & .54 \\
\hline 30.0 & 2500 & .577 \\
\hline 32.2 & 2690 & .632 \\
\hline 34.8 & 2880 & .704 \\
\hline 37.0 & 3110 & .312 \\
\hline 40 & 3200 & .93 \\
\hline 50 & 4200 & .530 \\
\hline
\end{tabular}


TABLE A- 6 (cont'd)

\begin{tabular}{|c|c|c|}
\hline GPM & $R E$ & $\Delta P_{S E}$ \\
\hline 60 & 5000 & 1.91 \\
\hline 70 & 5800 & 2.53 \\
\hline 80 & 6700 & 3.17 \\
\hline 90 & 7500 & 4,0 \\
\hline 100 & 8340 & 4.8 \\
\hline 110 & 9190 & 5.9 \\
\hline 120 & 10000 & 7.1 \\
\hline 130 & 10800 & 8,2 \\
\hline 140 & 11500 & 9.3 \\
\hline 150 & 12400 & 10.3 \\
\hline 160 & 13200 & 11,6 \\
\hline 170 & 14100 & 12,9 \\
\hline 180 & 14900 & 14.5 \\
\hline 190 & 15800 & 15.7 \\
\hline 200 & 16600 & 16.9 \\
\hline & & \\
\hline & & \\
\hline
\end{tabular}


TABLE $\quad \mathrm{-}-7$

SUBCHANNEL PRESSURE DROP DATA FOR THE FOUR' INCH LEAD BUNDLE (INTERIOR SUBCHANNET)

\begin{tabular}{|c|c|c|}
\hline $\mathrm{GPH}$ & RE & $\Delta \mathrm{P}_{\mathrm{SI}}$ \\
\hline 30 & 2000 & 0.397 \\
\hline 35 & 2300 & .496 \\
\hline 40 & 2600 & .614 \\
\hline 45 & 3000 & .758 \\
\hline 50 & 3300 & .938 \\
\hline 55 & 3600 & 1.010 \\
\hline 60 & 4000 & 1,155 \\
\hline 65 & 4300 & 1.263 \\
\hline 70 & 4600 & 1.371 \\
\hline 75 & 5000 & 1.516 \\
\hline 80 & 5300 & 1.696 \\
\hline 85 & 5600 & 1.913 \\
\hline 90 & 6000 & 2.129 \\
\hline 95 & 6300 & 2.238 \\
\hline 100 & 6600 & 2.526 \\
\hline 105 & 7000 & 2.779 \\
\hline 110 & 7300 & 3.031 \\
\hline
\end{tabular}


TABLE A7 (cont'd)

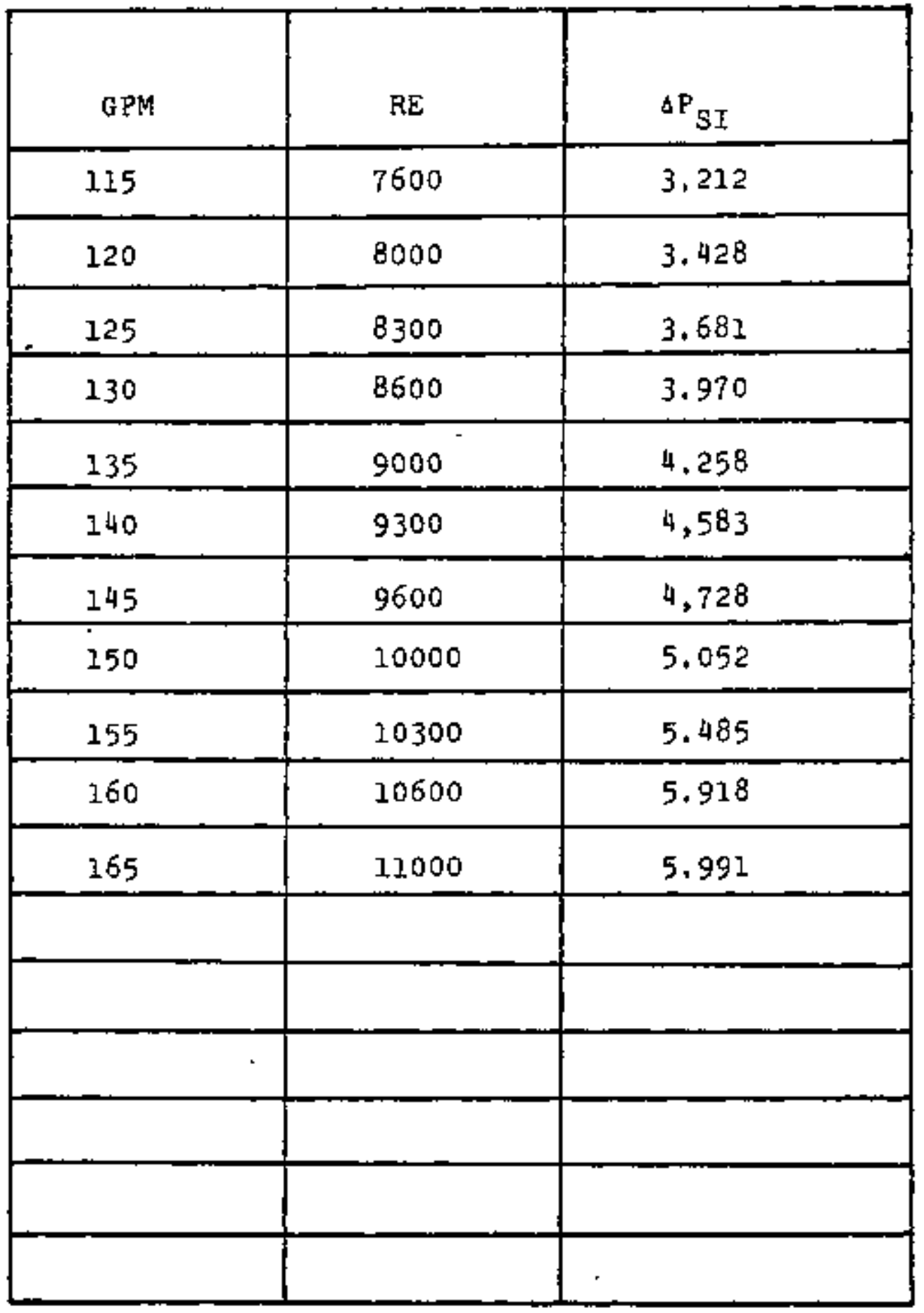


TABLE $A=8$

SUBCHANNEL PRESSURE DROP DATA FOR THE

FOUR INCH LEAD BUNDLE (EDGE SUBCHANNEL)

\begin{tabular}{|c|c|c|}
\hline GFM & $\mathrm{RE}$ & ${ }^{P_{S E}}$ \\
\hline 30 & 2000 & 0.397 \\
\hline 35 & 2300 & .496 \\
\hline 40 & 2600 & .541 \\
\hline 45 & 3000 & .722 \\
\hline 50 & 3300 & .866 \\
\hline 55 & 3600 & 1.010 \\
\hline 60 & 4000 & 1.191 \\
\hline 65 & 4300 & 1.299 \\
\hline 70 & 4600 & 1.407 \\
\hline 75 & 5000 & 1.552 \\
\hline 80 & 5300 & 1.660 \\
\hline 85 & 5600 & 1.840 \\
\hline 90 & 6000 & 2.093 \\
\hline 95 & 6300 & 2.201 \\
\hline 100 & 6600 & 2.346 \\
\hline 105 & 7000 & 2.670 \\
\hline 110 & 7300 & 2.851 \\
\hline
\end{tabular}


TABLE A-8 (cont'd)

\begin{tabular}{|c|c|c|}
\hline GPM & $\mathrm{RE}$ & $\Delta P_{S E}$ \\
\hline 115 & 7600 & 3.068 \\
\hline 120 & 8000 & 3.320 \\
\hline 125 & 8300 & 3.537 \\
\hline 130 & 8600 & 3.825 \\
\hline 135 & 9000 & 4.078 \\
\hline 140 & 9300 & 4.258 \\
\hline 145 & 9600 & 4.403 \\
\hline 150 & 10000 & 4.764 \\
\hline 155 & 10300 & 5.088 \\
\hline 160 & 10600 & 5.413 \\
\hline 165 & 11000 & 5.738 \\
\hline & & \\
\hline & & \\
\hline & & \\
\hline & & \\
\hline & & \\
\hline
\end{tabular}




\section{APPENDIX B}

\section{Error Analysis}

The error Involved in the determination of the friction factor $1 \mathrm{~s}$ composed of two parts: the experimental error in the subchannel pressure arop measurement and in the subchannel flow rate measurement, and the data reduction error. The data reduction error is malnly due to the amplification made in Eq. (4-2) to determine the bundle average pressure drop. Section (B-1) evaluates the maximum expected error involved in the subchannel pressure drop measurement and Sect. (B-2) evaluates the data reduction error. Section (B-3) relates these two errors and the experimental error involved in the determination of the average subchannel flow rate, to the errors Involved in the determination of the bundle average friction factors and the local subchannel friction factors.

B-1 Exper1mental Error in Subchannel Pressure Drop Measurement The experimental error is usualiy comprised of two types of errors: random error and systematic error. In this experiment, the random error results from the following factors:

1) fluctuation of the loop flow rate

2) misjudgement of the reading on the static pressure gauge

3) fluctuation of the subchannel local static pressure. The systematic error is mainly due to the deficlency of the stat1c pressure gauge. In what follows, we w11 evaluate all the errors corresponding to the aforementioned causes. 
In the evaluation of the random error, the component due to the fluctuation of the subchannel local static pressure can be omitted because of its high frequency nature (usually about 10 to $100 \mathrm{hz}$. The strain gauge used in this experiment does not respond to this high frequency fluctuation and in fact gives a very stable reading corresponding to the mean value of the subchannel static pressure. The fluctuation of the loop flow rate is not high frequency in nature. It usually takes about five seconds to go through a fluctuation cycle. This may cause errors in the determination of the static pressure from the straln gauge. The maximum expected error in the loop flow due to this fluctuation is estimated to be $3 \%$ by visually observing the fluctuation in the float of the loop flow rotameter. Th1s error in turn may cause an error in the determination of the subchannel static pressure of about $5 \%$ $(1.03)^{2}$ since the static pressure is proportional to the square of the velocity.

The random error involved in the reading of the static pressure gauge is about t0.1 inch of water. Therefore, this leads to about $\pm 15 \%$ error in the determination of the static pressure drop at the bundle Reynolds number of 200. However, this error will decrease as the bundle flow rate increases since the static pressure drop increases as the bundle flow rate increases, and since this error is determined by the ratio of the abservation error to the total subchannel pres- 
sure drop. For example, at a Reynolds number of 500, this error can only cause $\pm 7.5 \%$ uncertainty in the determination of the pressure drop, and at bundle Reynolds number 1000, this error will 1nduce only $\pm 3 \%$ uncertainty in the determination of the subchannel pressure drop. For reasons of conservatism, a 3\% error is imposed on the static pressure drop determination for a bundle Reynolds number larger than 1000.

The systemat1c error due to the accuracy of the pressure gauge is estinated to be \pm 1 . The gauges were calibrated to this accuracy by the manufacturer before this experiment was performed.

From the above discussion, we can evaluated the total experimental error as the sum of the total random error from the statistical combination of the loop flow fluctuation and the experimenter's misjudgement in reading the static pressure gauge plus the systematic error due to accuracy of the pressure gauge. Thus, the total errors are:

Experimental total error $= \pm\left(\sqrt{0.06^{2}+0.03^{2}}+0.01\right)$

$$
= \pm 7.7 \% \text { for } \operatorname{Re}>1000
$$

and

Experimental total error $= \pm\left(\sqrt{0.06^{2}+0.075^{2}}+0.01\right)$

$$
= \pm 9.6 \% \text { at } \operatorname{Re}=500
$$

and

Experimental total error $= \pm\left(6.06^{2}+0.15^{2}+0.01\right)$

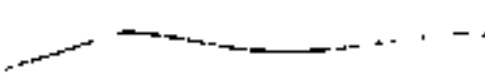

$$
\pm 17.2 \% \text { at } \operatorname{Re}=200
$$




\section{B-2 Error in Data Reduction}

The simplification. made in Eq. (4-2) to determine the bundle average pressure is based on the assumption that the pressure drops for all the Interior subchannels over a certain subchannel length are the same and that the pressure drop for all the edge subchannels over a certain subchannel length are also the same. This assumption is deduced from the experimental fact that the subchannel flow rates for all the interfor subchannels are not affected by the existence of the edge subchannels even for those interfor subchannels located near the edge subchannels (Ref. 4). This feature implies that the hydraulic characteristics of the interior subchannels depend only on their own geometric parameters. Since the geometric characteristics for all the Interior subchannels are the same, It is expected that the interior subchannel pressure drops w1ll be the same over a certain subchannel length.

However, if the above deduction is wrong, 1.e., if the Interior subchannel pressure drop is not the same for every interior subchannel, an error will result from the use of Eq. (4-2) In the determination of $P_{b}$. For the sake of conservatism, we assume that the pressure drop of the average interior channel is midway between that of our measured center interior channel and edge channel, 1.e.:$$
F_{s 1} *\left(P_{s 1}+P_{s 2}\right) / 2.0
$$$$
\text { where } P_{S I} \text { is the subchannel pressure drop for the }
$$$$
\text { center interior subchannel. }
$$ 
Thus, the total data reduction error in $\mathrm{P}_{b}$ becomes

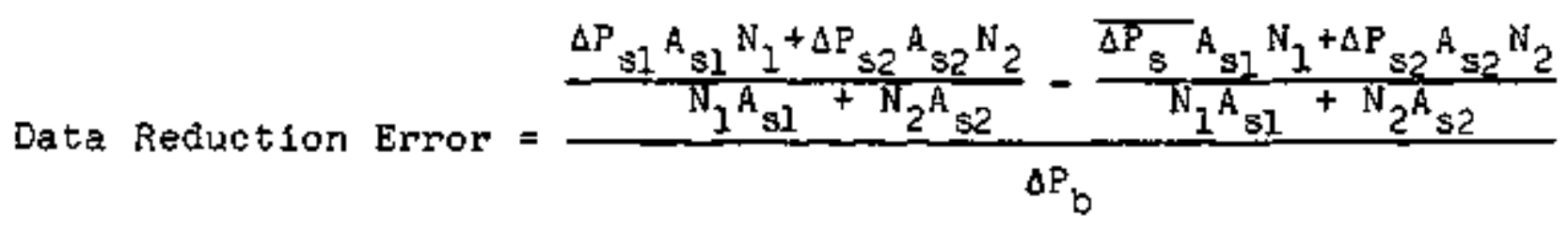

Inserting Eq. (B-4) into the above equation, we obtain:

Data Reduction Error $=\frac{0.5\left(\Delta \mathrm{P}_{\mathrm{s} 1}-\Delta \mathrm{P}_{\mathrm{s} 2}\right)}{0.5 d \mathrm{P}_{\mathrm{sl}}+\Delta \mathrm{P}_{\mathrm{s} 2}\left(\mathrm{~A}_{\mathrm{s} 2} \mathrm{~N}_{2} / \mathrm{A}_{\mathrm{s} 1} \mathrm{~N}_{1}+0.5\right)}$

In this experiment, $\left(\mathrm{A}_{s 2} \mathrm{~N}_{2} / \mathrm{A}_{s 1} \mathrm{~N}_{1}\right)=0.545$, therefore $\mathrm{Eq} .(\mathrm{B}-6)$ becontes:

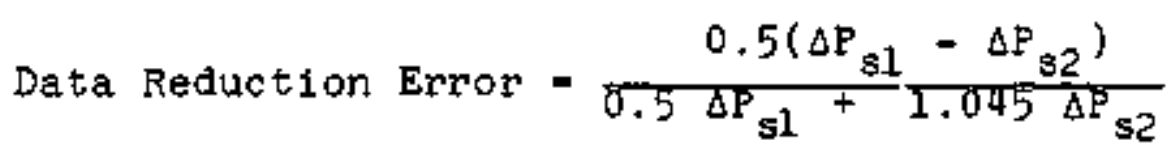

Inserting the experimental data of $\Delta \mathrm{P}_{\mathrm{s} 1}$ and $\Delta \mathrm{P}_{\mathrm{s} 2}$ into the above equation, we find the maximum data reduction error in $\Delta \mathrm{F}_{\mathrm{b}}$ to be equal to $3.8 \%$ which corresponds to a bundle flow of $1650 \mathrm{PM}$ in the four inch lead bundle.

B-3 Total Error in the Determination of the Friction Factors From the following relationship between friction factors and the pressure drop:

$$
\Delta P=\mathrm{f} \frac{\mathrm{L}}{\mathrm{De}} \frac{\mathrm{pV^{2 }}}{2 \mathrm{~g}_{\mathrm{c}}}
$$


we can relate the error in the determination of $A P$ and $V$ to the error in the friction factor by changing the above equation into its differential form, $1 . e$.,

$$
\delta(\Delta P)=\frac{L}{D e} \frac{\rho V^{2}}{2 g_{c}} \delta f+f \frac{L U}{D e}(\delta V) .
$$

Rearranging the above equation, we obtain

$$
\left(\frac{\delta f}{f}\right)=\frac{\delta \Delta P}{\Delta P}+2\left(\frac{\delta V}{V}\right)
$$

where $\frac{\delta f}{f}=$ relative error in the determination of the friation factor

$$
\begin{aligned}
\frac{\delta \Delta P}{\Delta P}= & \text { relative error in the determination of the } \\
& \text { pressure drop } \\
\frac{\delta V}{V}= & \text { relative error in hte determination of the } \\
& \text { velocity }
\end{aligned}
$$

The Eq. (B-IO) is a general equation to determine the relative error in the determination of the friction factor. Therefore, to detormine the error in the bundle atrerage friction factor, the errors in the determination of the bunde average pressure drop and the bundle average velocity should be taken into account. For the error in the subchannel friction factor, the errors in the determination of the subchannel pressure drop and the subchannel average veloctty should be taken into account. Section (B-3-1) evaluates the error 1nvolved in the determination of the bundle average friction factor and sect. $(B-3-2)$ evaluates the error involved in the 
determination of the local subchannel friction factors for both interior and edge subchannels.

\section{B-3-1 Error in Bundle Average Friction Factors}

The error in the bundle average friction factor is induced by the errors involved in the determinations of $\Delta P_{b}$ and of the bundle average velocity. The error $1 n \Delta P_{b}$ is comprised of two components: the data reduction error and the subchannel pressure drop measurement error. Thus, the error involved in the determination of $\Delta F_{b}$ is equal to

$$
\begin{aligned}
& \frac{\delta \Delta \mathrm{P}_{\mathrm{b}}}{\Delta \mathrm{P}_{\mathrm{b}}}=\text { data reduction error }+ \text { measurement error } \\
& = \begin{cases}11.5 \% & \text { for } \mathrm{Re}>1000 \\
13.4 \% & \text { at } \mathrm{Re}=500 \\
21.0 \% & \text { at } \mathrm{Re}=200 .\end{cases}
\end{aligned}
$$

At the same time, we know that $\frac{\hat{V}}{\mathrm{~V}}$ 1s equal to the error in the determination of the loop flow, evaluated in sect. (B-l) to be $\pm 3 \%$. Therefore, the error inherent in the bundle average friction factor can be evaluated from $\mathrm{Eq}$. (B-I1). The results are stated as follows:

$$
\frac{\delta \mathbf{f}}{\mathbf{f}}= \begin{cases}17.5 \% & \text { for } \operatorname{Re}>1000 \\ 19.4 \% & \text { at } \operatorname{Re}=500 \\ 27.0 \% & \text { at } \operatorname{Re}=200 .\end{cases}
$$


B-3-1 Error in Local Subchannel Friction Factor

The error involved in the determination of the local

subchannel friction factor is induced from the errors involved in the determinations of the subchannel pressure drop and of the subchannel average velocities. In Ref. (4), the error of $\frac{6 \mathrm{~V}}{\mathrm{~V}}$ is evaluated to be $\pm 5 \%$. The error of the subchannel pressure measurement, $1 . e ., \frac{\delta \Delta \mathrm{P}_{3}}{\Delta \mathrm{P}_{\mathrm{S}}}$, is estimated in Sect. (B-1) to be

$$
\frac{\delta \Delta \mathrm{P}_{\mathrm{S}}}{\Delta \mathrm{P}_{\mathrm{S}}}= \begin{cases} \pm 7.7 \% & \text { for Re }>1000 \\ \pm 9.6 \% & \text { at } \mathrm{Re}=500 \\ \pm 17.2 \% & \text { at } \mathrm{Re}=200 .\end{cases}
$$

From Eq. (B-10) and the above information, the relative error in the local subchannel error is evaluated as:

$$
\frac{\delta f}{f}= \begin{cases} \pm 17.7 \% & \text { for Re } 1000 \\ \pm 19.6 \% & \text { at Re }=500 \\ \pm 27.2 \% & \text { at Re }=200 .\end{cases}
$$


[1] C. Chiu, N.E. Todreas and W.M Rohsenow, "Blxing Exper1ment in LMFBR Blanket Assemblies," to be Issued as a topic report coo-2245-39TR, Department of Nuclear Engineering, M.I.I., 1977 .

[2] K. Rehme, "Pressure Drop Correlations for Fuel Element Spacers," Nuclear Technology, Vol. I7, (15-21), January 1973.

[3] E.H. Novendstern, "Turbulent Flow Pressure Drop Model for Full Rod Assemblies Ut1lizing a Helical W1re-wrap Spacer System, "Nuclear Engineering and Design, 22-1, August, 197 .

[4] C. Chiu, N.E. Todreas and W.M. Rohsenow, "Flow Split Measurements in LMFBR Blanket Assemblies," to be issued as a topic report CO0-2245-45TR, Nuclear Engineering Department, M.I.T., 1977.

[5] C. Chiu, W.M. Rohsenow and N.E. Todreas, "Flow Split Model for LMFBR Wire Wrapped Assemblies", C00-2245-56TR, Department of Nuclear Engineering, M.I.T. December, 1977. 